\title{
Controle de soluções sanificantes por meio do potencial de óxido-redução em alface americana minimamente processada
}

Sílvia Regina Reis Santaella

Tese apresentada ao Programa de PósGraduação em Saúde Pública da Faculdade de Saúde Pública da Universidade de São Paulo para obtenção do título de Doutor em Saúde Pública

Área de Concentração: Serviços de Saúde

Orientador: Prof. Dr. Glavur R. Matté

São Paulo

2007

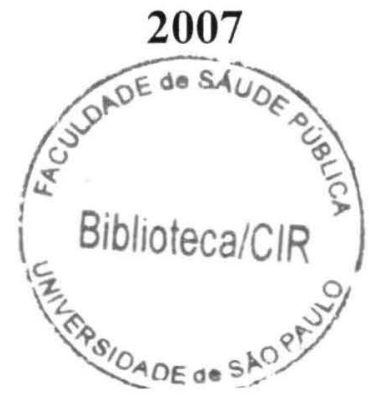


É expressamente proibida a comercialização deste documento tanto na sua forma impressa como eletrônica. Sua reprodução total ou parcial é permitida exclusivamente para fins acadêmicos e científicos, desde que na reprodução figure a identificação do autor, título, instituição e ano da tese/dissertação.

$$
49288 \mid 2008 \text { doc }
$$


Dedico este trabalho à memória de

Esther Salvador Reis Santaella

Maria Cecília Vicari

Sebastião Timo laria 
Agradeço

ao Aurélio pela companhia,

à professora Maria Helena pelas sugestões e participação no desenvolvimento laboratorial,

à técnica Maria do Carmo pelo auxílio nas análises químicas,

aos colegas do laboratório e especialmente à Miriam pela força e empolgação,

ao professor Glavur pela orientação. 
Santaella SRR. Controle de soluções sanificantes por meio do potencial de óxido-redução em alface americana minimamente processada. São Paulo; 2007. [Tese de doutorado - Faculdade de Saúde Pública da USP].

A presença no mercado brasileiro de hortifrutícolas minimamente processadas atende a uma demanda por produtos prontos para consumo, decorrente das alterações econômicas e socioculturais ocorridas na população. As avaliações microbiológicas desses produtos têm revelado inadequação aos padrões da legislação sanitária. O reaproveitamento das soluções sanificantes é uma prática comum e a eficácia desses métodos necessita ser avaliada. Neste trabalho, objetivou-se quantificar o material oxidável desprendido em imersões sucessivas de alface americana por meio da demanda quimica de oxigênio (DQO) e verificar sua interferência na ação de sanificantes comerciais. Foram testadas as soluções de hipoclorito de sódio (Virex Plus FLV 2\%®), dióxido de cloro estabilizado (Tecsaclor®) e dicloro-S-triazinatriona sódica diidratada (Sumaveg®) preparadas segundo a orientação do fabricante, nos tempos de contato de 2, 5, 10 e 15 min contra E. coli ATCC 11229. O comportamento da reação química de contato dos sanificantes, da matéria orgânica e do inóculo foi medido por meio do potencial de óxido-redução (POR) e contagem dos microrganismos viáveis após os tempos de contato. As soluções de dióxido de cloro e dicloro-S- 
triazinatriona apresentaram mais de 5 reduções logarítmicas na população inicial. A solução de hipoclorito de sódio apresentou variabilidade na eficácia na presença da matéria orgânica, tanto na solução preparada no momento do uso como na solução "envelhecida". Discute-se também a viabilidade do uso de um medidor portátil de POR como um instrumento de campo para controle da desinfecção de hortifrutícolas.

Descritores: Vegetais. Hortaliça. Alimento pronto para consumo. Oxidante. Demanda química de oxigênio. Microbiologia. 
Santaella SRR. Sanitizers' control by means of oxidation-reduction potential on minimally processed Iceberg Lettuce. Sao Paulo; 2007. [Doctoral thesis - School of Public Health - University of Sao Paulo].

The presence of fruits and vegetables minimally processed fulfils a consumer demand for ready-to-eat products, as a result of economic and sociocultural changes within the population. Microbiological evaluation of these products has revealed inappropriate conformation to sanitary legislation standards. Reuse sanitizing solution is a conventional practice and the efficiency of these methods needs to be assessed. This paper aimed to quantify organic matter from Iceberg Lettuce susceptible to oxidation over repeated washes by means of chemical oxygen demand (COD) and to verify its interference on commercial sanitizers action. Solutions of sodium hypochlorite (Virex Plus FLV $2 \% ®)$, stabilized chlorine dioxide (Tecsaclor®) and sodium dichlorine-Striazinatrione dihydrate (Sumaveg ${ }^{\circledR}$ ) prepared according to manufacturers' manuals, were tested over 2, 5, 10 and 15 minutes of contact against $E$. coli ATCC 11229. Contact chemical reaction performance of sanitizers, organic matter and inoculum were measured by means of oxidation-reduction potential (ORP) and viable microorganisms counting after each contact period. Stabilized chlorine dioxide and sodium dichlorine-S-triazinatrione dihydrate presented more than 5 logarithmic reductions compared to initial population. Sodium hypochlorite has shown efficacy variability in the 
presence of organic matter, in both newly prepared and "aged" solution. In this paper is also examined the viability of using an ORP portable measurement device as a field instrument to assess the disinfection of vegetables.

Descriptors: Vegetables. Ready-to-eat. Oxidizer. Chemical oxygen demand. Microbiology. 


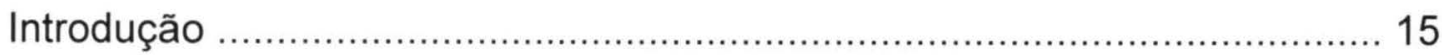

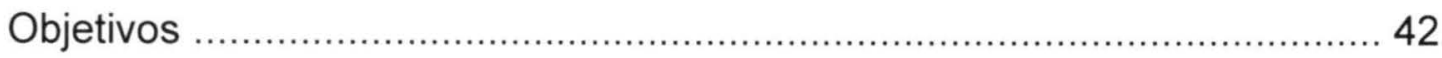

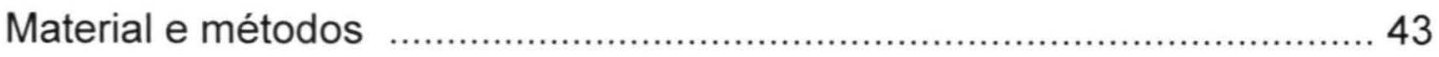

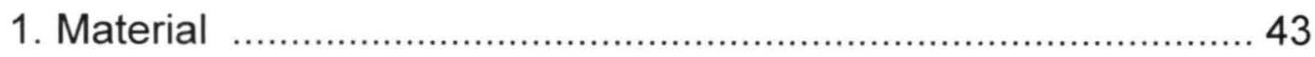

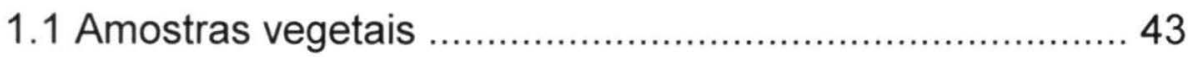

1.2 Cepa padrão Escherichia coli ATCC 11229 ..................... 43

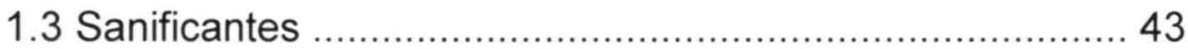

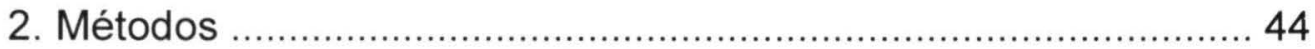

2.1 Preparo das imersões de alface americana ..................... 44

2.2 Determinação da demanda química de oxigênio (DQO), método do refluxo aberto segundo GREENBERG et al. 1992.

2.3 Preparo do inóculo ........................................................ 46

2.4 Enumeração de células de E. coli ................................... 47

2.5 Preparo das soluções sanificantes ................................... 47

2.6 Teste do medidor do potencial de óxido-redução (POR) nas

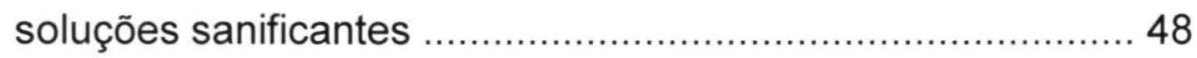

2.7 Teste de eficácia dos sanificantes em presença de matéria orgânica proveniente de banhos de alface americana .......... 49

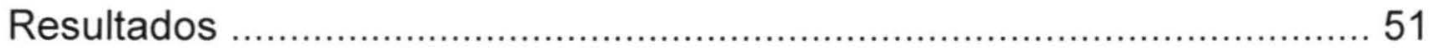

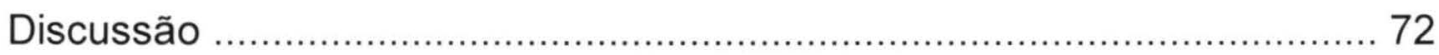

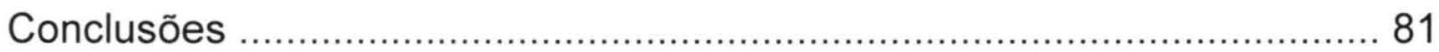


Recomendações

Bibliografia 83 
Tabela 1 - Tempo de resistência de E. coli O157:H7, Salmonella spp, Listeria monocytogenes e coliforme termotolerante em três faixas de potencial de oxido-redução

Tabela 2 - Demanda química de oxigênio (DQO) em miligrama de oxigênio por litro $\left(\mathrm{mg} \mathrm{O}^{2} / \mathrm{L}\right)$ segundo número de imersões de alface americana em água Milli-Q

Tabela 3 - Potencial de óxido-redução em milivolts $(\mathrm{mV})$ segundo o tempo de contato da cepa padrão $E$. coli com o sanificante dióxido de cloro estabilizado $\left(\mathrm{ClO}_{2}\right.$, Tecsaclor®) nas diferentes proporções de alface americana por imersão em água, ensaio 1

Tabela 4 - Potencial de óxido-redução em milivolts $(\mathrm{mV})$ segundo o tempo de contato da cepa padrão E. coli com o sanificante hipoclorito de sódio ( $\mathrm{NaClO}$, Virex Plus FLV 2\%®, 200 mg/L) nas diferentes proporções de alface americana por imersão em água, ensaio 2

Tabela 5 - Potencial de óxido-redução em milivolts $(\mathrm{mV})$ segundo o tempo de contato da cepa padrão E. coli com a solução "envelhecida" do sanificante hipoclorito de sódio ( $\mathrm{NaClO}$, Virex Plus FLV $2 \% ®, 200 \mathrm{mg} / \mathrm{L}$ ) nas diferentes proporções de alface americana por imersão em água, ensaio 3

Tabela 6 - Potencial de óxido-redução em milivolts $(\mathrm{mV})$ segundo o tempo de contato com a solução "envelhecida" do sanificante dicloro-Striazinatriona sódica diidratada $\left(\mathrm{NaCl}_{2} \mathrm{C}_{3} \mathrm{~N}_{3} \mathrm{O}_{3}\right.$, Sumaveg®, $\left.200 \mathrm{mg} / \mathrm{L}\right)$ nas diferentes proporções de alface americana por imersão em água, ensaio 4

Tabela 7 - Contagens de E. coli ATCC 11229 recuperadas em imersões contendo matéria orgânica e sanificante, em diferentes tempos de contato, nos quatro ensaios realizados 68

Tabela 8 - Número em escala logarítmica de unidades formadoras de colônias de E. coli ATCC 11229 reduzidas em imersões contendo matéria orgânica e sanificante, nos ensaios com hipoclorito de sódio (ensaios 2 e 3) 
Figura 1 - Esquema dos testes de eficácia dos sanificantes em banhos contendo matéria orgânica

Figura 2 - Comportamento da água sem imersão (controle) e três imersões sucessivas* contendo matéria orgânica proveniente dos cortes de alface americana** segundo o potencial de óxido-redução (POR) em milivolts ( $\mathrm{mV}$ ), ao longo de 10 minutos de contato do inóculo de $E$. coli com dióxido de cloro estabilizado $\left(\mathrm{ClO}_{2}\right.$, Tecsaclor®), ensaio 1

Figura 3 - Comparação da curva de demanda química de oxigênio (DQO) em $\mathrm{mg} \mathrm{O}^{2} / \mathrm{L}$ com o potencial de óxido-redução em milivolts $(\mathrm{mV})$ de três tempos de contato do dióxido de cloro estabilizado $\left(\mathrm{ClO}_{2}\right.$, Tecsaclor®) com o inóculo de $E$. coli em água sem imersão (controle) e mais quatro imersões sucessivas contendo matéria orgânica proveniente dos cortes de alface americana*, ensaio 1

Figura 4 - Comportamento da água sem imersão (controle) e mais oito imersões sucessivas com matéria orgânica proveniente dos cortes de alface americana* segundo o potencial de óxido-redução (POR) em milivolts ( $\mathrm{mV}$ ), ao longo de 15 minutos de contato do inóculo de $E$. coli com o sanificante hipoclorito de sódio ( $\mathrm{NaClO}$, Virex Plus FLV 2\%®, 200 mg/L), ensaio 2 ....60

Figura 5 - Comparação da curva de demanda química de oxigênio (DQO) em $\mathrm{mg} \mathrm{O}^{2} / \mathrm{L}$ com o potencial de óxido-redução em milivolts $(\mathrm{mV})$ de quatro tempos de contato do hipoclorito de sódio ( $\mathrm{NaClO}$, Virex Plus FLV 2\%®, 200 $\mathrm{mg} / \mathrm{L}$ ) com o inóculo de $E$. coli em água sem imersão (controle) e mais oito imersões sucessivas contendo matéria orgânica proveniente dos cortes de alface americana*, ensaio 2

Figura 6 - Comportamento da água sem imersão (controle) e mais oito imersões sucessivas contendo matéria orgânica proveniente dos cortes de alface americana* segundo o potencial de óxido-redução (POR) em milivolts $(\mathrm{mV})$, ao longo de 15 minutos de contato do inóculo de $E$. coli com a solução "envelhecida"** de hipoclorito de sódio ( $\mathrm{NaClO}$, Virex Plus FLV 2\%®, 200 $\mathrm{mg} / \mathrm{L})$, ensaio 3

Figura 7 - Comparação da curva de demanda química de oxigênio (DQO) em $\mathrm{mg} \mathrm{O}^{2} / \mathrm{L}$ com o potencial de óxido-redução em milivolts $(\mathrm{mV})$ de quatro tempos de contato da solução "envelhecida"* de hipoclorito de sódio ( $\mathrm{NaClO}$, Virex Plus FLV 2\%®, $200 \mathrm{mg} / \mathrm{L}$ ) com o inóculo de $E$. coli em água sem imersão (controle) e mais oito imersões sucessivas contendo matéria orgânica proveniente dos cortes de alface americana**, ensaio 3 
Figura 8 - Comportamento da água sem imersão (controle) e mais oito imersões sucessivas contendo matéria orgânica proveniente dos cortes de alface americana* segundo o potencial de óxido-redução (POR) em milivolts $(\mathrm{mV})$, ao longo de 15 minutos de contato do inóculo de E. coli com uma solução "envelhecida"** de dicloro-S-triazinatriona sódica diidratada $\left(\mathrm{NaCl}_{2} \mathrm{C}_{3} \mathrm{~N}_{3} \mathrm{O}_{3}\right.$, Sumaveg $\left.{ }^{\circledR}, 200 \mathrm{mg} / \mathrm{L}\right)$, ensaio 4

Figura 9 - Comparação da curva de demanda química de oxigênio (DQO) em $\mathrm{mg} \mathrm{O}^{2} / \mathrm{L}$ com o potencial de óxido-redução em milivolts $(\mathrm{mV})$ de quatro tempos de contato da solução "envelhecida"* de dicloro-S-triazinatriona sódica diidratada $\left(\mathrm{NaCl}_{2} \mathrm{C}_{3} \mathrm{~N}_{3} \mathrm{O}_{3}\right.$, Sumaveg $\left.{ }^{\circledR}, 200 \mathrm{mg} / \mathrm{L}\right)$ com o inóculo de $E$. coli em água sem imersão (controle) e mais oito imersões sucessivas contendo matéria orgânica proveniente dos cortes de alface americana ${ }^{\star *}$, ensaio 4

Figura 10 - Contagem de E. coli nas imersões utilizando solução de hipoclorito de sódio, ensaio 2 70

Figura 11 - Contagem de E. coli nas imersões utilizando solução "envelhecida" de hipoclorito de sódio, ensaio 3 


\section{Introduçăo}

Os alimentos minimamente processados podem ser definidos como produtos hortifrutícolas higienizados e embalados que foram submetidos a processos técnicos, preservando suas características sensoriais naturais, tornando-os prontos para o consumo in natura ou para preparo culinário (SANTAELLA et al. 2006).

A disposição no mercado de alimentos minimamente processados atende à demanda por produtos práticos e frescos decorrente de alterações como a urbanização, a entrada massiva da mulher no mercado de trabalho e a mudança no estilo de vida dos consumidores.

As rápidas alterações econômicas e socioculturais que vêm ocorrendo na população brasileira nos últimos 50 anos são também acompanhadas por modificações no seu perfil demográfico e epidemiológico. A redução da taxa de mortalidade infantil causou um aumento percentual da população de adultos, elevando conseqüentemente o peso dos fatores de risco para doenças não-transmissíveis, que atingem principalmente as pessoas de meia-idade (BANCO MUNDIAL 2005).

Segundo relatório do BANCO MUNDIAL (2005), 5,4\% das mortes ocorridas na América Latina e Caribe, entre os países com baixa mortalidade (incluindo o Brasil), têm como fator de risco a baixa ingestão de frutas e vegetais.

As pesquisas que investigam o consumo de alimentos das famílias brasileiras realizadas nos últimos 30 anos pelo Instituto Brasileiro de 
Geografia e Estatística (IBGE 2004) apontam para uma importante mudança no padrão alimentar. O consumo médio per capita dos alimentos de base tradicionais do cardápio brasileiro diminuiu $46 \%$, no caso do arroz, e $37 \%$, no do feijão, ao longo do período de pesquisa. Por outro lado, o consumo de alimentos preparados aumentou $216 \%$.

SCHLINDWEIN (2006) demonstrou que o maior nível de escolaridade da mulher propicia a aquisição de alimentos poupadores de tempo (iogurtes, refrigerantes, alimentos prontos e alimentação fora de casa) em detrimento dos classificados como tempo intensivos (arroz, feijão, batata, mandioca, carnes e farinha de trigo), que demandam mais tempo para o preparo. Este comportamento também é percebido quando a mulher é chefe de família ou para mulheres mais jovens. Um aumento de $10 \%$ na renda eleva o consumo de alimentos preparados em $8 \%$.

A modificação nas práticas alimentares brasileiras vem acompanhada de mudanças negativas sob o aspecto nutricional - a substituição dos grãos e cereais por alimentos de origem animal, gorduras, açúcares, alimentos industrializados, e que são de uma maneira geral pobres em carboidratos complexos e fibras (MINISTÉRIO DA SAÚDE 2005). Os novos padrões de trabalho e lazer também contribuem negativamente, pois propiciam o baixo gasto energético, o sobrepeso e o sedentarismo que irão levar ao aumento na pressão arterial, colesterol e diabetes, que por sua vez vão ocasionar as doenças no coração, rins, derrames, câncer e outras doenças nãotransmissíveis no país (BANCO MUNDIAL 2005). 
Como estratégias de enfrentamento de curto e médio prazo, o relatório do BANCO MUNDIAL (2005) propõe o fortalecimento da merenda escolar com hortifrutícolas e campanhas por meio da mídia, dos servidores da saúde e de grupos comunitários para escolha de alimentos saudáveis.

DIEZGARCIA (2003) observa que a opção por facilidades que poupam tempo de preparo e diminuem a freqüência de compras é característica do consumidor contemporâneo. A autora exemplifica esta afirmativa com o caso do leite longa vida que nos anos de 1990 a 1996 teve sua produção aumentada em $90 \%$, e o leite pasteurizado reduzida em $35 \%$ no mesmo período. A agilidade dos alimentos fast food, que poupam tempo de preparo, ingestão e podem ser transportados para qualquer espaço, combina com o mundo contemporâneo. A chave do sucesso das cadeias de fast food está no alinhamento com o modo de vida atual, e menos por seu traço cultural "americano".

Do ponto de vista da saúde pública, para uma intervenção como sugere o BANCO MUNDIAL (2005), será necessário agir dentro dos princípios do novo estilo de vida dos consumidores. Alimentos com menor densidade calórica devem competir nas vitrines com os fast food tradicionais, alimentos prontos e semiprontos em geral, pois o consumo de verduras, legumes e frutas contribui para a variedade da alimentação e oferta de micronutrientes. $\mathrm{O}$ aumento no consumo desses alimentos pode promover a redução de alimentos inadequados com elevado teor de gordura, sal e açúcar na dieta. 


\section{Pesquisas: consumo e contaminação}

Pesquisas realizadas com consumidores nos setores de frutas, legumes e verduras (FLV) de supermercados do Estado de São Paulo, Rio de Janeiro e Minas Gerais pelo MINISTÉRIO DA INTEGRAÇÃO NACIONAL (1999, 2002 e 2003) sugerem que 12\% dos domicílios do Estado de São Paulo consomem algum tipo de hortifrutícola minimamente processada. Mas o volume consumido em relação ao consumo total de FLV por familia representou em média somente 2,9\%. No Rio de Janeiro e em Minas Gerais a participação de hortifrutícolas minimamente processadas foi de apenas 1\%. Considerando somente os consumidores da Grande São Paulo, essa participação sobe para 3,3\% (MINISTÉRIO DA INTEGRAÇÃO NACIONAL 2002).

Para os consumidores classificados como das classes A/B do Estado de São Paulo, a participação dos produtos minimamente processados atingiu $4,2 \%$ no total de produtos de FLV consumidos. Em todas as pesquisas mais de $75 \%$ dos consumidores eram mulheres. Na primeira pesquisa realizada em São Paulo verificou-se que entre os que compram produtos minimamente processados, $74 \%$ justificam pela praticidade, $86 \%$ são mulheres com segundo grau ou nível superior completos e com renda $24 \%$ superior aos que não consomem este tipo de produto. A pesquisa também constatou que os preços das hortifrutícolas minimamente processadas eram $180 \%$ a $400 \%$ mais caros que o mesmo tipo de produto a granel (MINISTÉRIO DA INTEGRAÇÃO NACIONAL 1999). 
Se atualmente a escolha por alimentos recai sobre os produtos "rápidos", por que o consumo de hortifrutícolas minimamente processadas é baixo entre os consumidores de FLV?

O perfil dos consumidores que não compram sugere que o custo do alimento pesa mais que a praticidade na sua decisão de compra. Segundo o MINISTÉRIO DA INTEGRAÇÃO NACIONAL (1999), dentre os consumidores que não compram, $30 \%$ alegam que os produtos minimamente processados são caros, além de outras razões como qualidade (36\%) e higiene (25\%).

Vários fatores têm de ser levados em consideração pelo consumidor para a comparação do custo entre o produto minimamente processado e um correspondente disponível para venda a granel. Em primeiro lugar, o rendimento da matéria-prima - um quilograma de qualquer hortifrutícola não rende o mesmo peso em produto pronto. Se levar em consideração a padronização de tamanho, cor etc., o rendimento pode ser ainda menor. A mistura de diferentes hortaliças numa mesma preparação demanda a aquisição de um volume de matérias-primas que pode não ser consumido antes que se estrague. Há outros custos menores que também podem ser considerados como o da água, do sanificante e do tempo que o consumidor irá dispor para o preparo. Como demonstrado por SCHLINDWEIN (2006), o valor do tempo de preparo vai depender do custo de oportunidade do tempo, isto é, profissionais mais bem pagos têm o tempo mais caro.

As pesquisas realizadas por órgãos de defesa dos consumidores com alimentos minimamente processados têm sido amplamente divulgadas pela mídia. Os resultados não são bons e com certeza impactam na opinião do 
consumidor. A pesquisa divulgada em 2004 pelo Instituto de Defesa do Consumidor (IDEC) envolveu 25 amostras de agrião, alface e cenoura minimamente processados e concluiu que $36 \%$ das amostras estavam contaminadas por coliformes fecais, além de declararem ter encontrado preços até $2000 \%$ superiores ao produto a granel (IDEC 2004).

Outra pesquisa divulgada na mídia foi realizada pela Associação Brasileira do Consumidor, que avaliou treze amostras de alface e cenoura minimamente processadas. A pesquisa aprovou os produtos quanto aos resíduos de pesticidas, mas em todas as saladas de alface foram encontradas pragas agrícolas (pulgões). As cenouras minimamente processadas foram aprovadas, porém o custo também foi apontado como elevado, cerca de $400 \%$ superior em relação ao produto comercializado a granel (MINISTÉRIO DO DESENVOLVIMENTO, INDÚSTRIA E COMÉRCIO EXTERIOR 2004).

A produção de alimentos minimamente processados deverá se adaptar ao mercado para expandir ainda mais sua participação e ganhar em escala, mas para isto, além do preço, precisará conquistar a confiança do consumidor com relação aos atributos de qualidade e higiene.

Nos últimos anos foram realizadas várias pesquisas em diferentes locais do Brasil para averiguar a qualidade microbiológica de hortifrutícolas minimamente processadas.

FRÖDER (2005) analisou 181 hortaliças folhosas minimamente processadas adquiridas em estabelecimentos comerciais da cidade de São Paulo. Em apenas uma amostra $(0,6 \%)$ foi verificada a contaminação por 
Listeria monocytogenes. Em 133 destas amostras foram também realizadas pesquisas de microrganismos psicrotróficos aeróbios, Enterobacteriaceae, coliformes totais e fecais e Salmonella spp. O autor observou que das 133 amostras, $51 \%$ apresentaram populações de microrganismos psicrotróficos aeróbios superiores a $10^{6} \mathrm{UFC} / \mathrm{g}$ e $42 \%$ apresentaram populações de Enterobacteriaceae entre $10^{5}$ a $10^{6} \mathrm{UFC} / \mathrm{g}$, coliformes totais e fecais acima de $10^{2} \mathrm{UFC} / \mathrm{g}$ em 97 amostras (73\%) e Salmonella spp foi detectada em quatro amostras (3\%).

Na cidade de Londrina, Paraná, foi realizado um estudo envolvendo dez hortaliças minimamente processadas amostradas em hipermercados, sendo que oito dessas amostras eram produzidas no próprio estabelecimento e duas provinham de uma indústria. Os autores constataram que todas as amostras apresentavam coliformes totais e fecais, e que em oito delas o número mais provável de coliformes fecais por grama (NMP/g) era acima de 100, inclusive nas produzidas na indústria (FURLANETO et al. 2005).

Em um estudo realizado por BONNAS et al. (2005) em Uberlândia, Minas Gerais, foram encontrados resultados semelhantes: das dez amostras pesquisadas, em todas foram constatadas contagens de coliformes fecais, sendo que em nove delas o número mais provável de coliformes fecais era superior a 100/g. Os locais de amostragem foram: feira (três amostras), sacolão (cinco amostras), loja de conveniência (uma amostra) e supermercado (uma amostra). 
SANTOS et al. (2005) analisaram 30 amostras de cenouras minimamente processadas provenientes de dois supermercados da cidade de Teresina, Piauí. E coli foi isolada em $43,3 \%$ das amostras estudadas. Não foi detectada a presença de Salmonella spp nas pesquisas realizadas.

Também no nordeste brasileiro, em Fortaleza, no Ceará, BRUNO et al. (2005) realizaram uma pesquisa da qualidade microbiológica de 30 produtos hortifrutícolas minimamente processados. Os resultados apontaram que duas das cinco amostras de salada de frutas continham Salmonella spp. O mesmo número de amostras positivas para Salmonella spp foi encontrado na pesquisa das cinco amostras de abacaxi minimamente processado, mas em ambos os casos o número mais provável de coliformes fecais por grama era inferior a 100. Entre as quinze amostras de hortaliças minimamente processadas, dez foram consideradas positivas para Salmonella spp e dentre estas somente uma apresentava contagem de coliformes fecais acima de $100 \mathrm{NMP} / \mathrm{g}$. Considerando o total da pesquisa, 13\% das amostras continham NMP/g de coliformes fecais acima de 100.

Na cidade de Ribeirão Preto, São Paulo, foi realizado um estudo a partir da análise de 61 hortaliças minimamente processadas. Não foi detectada Salmonella spp em nenhuma das amostras estudadas. A presença de aeróbios psicrotrófilos variou de $10^{4}$ a 4,0 × $10^{10} \mathrm{UFC} / \mathrm{g}$; coliformes a $45^{\circ} \mathrm{C}$ entre 0 e $2,4 \times 10^{4} \mathrm{NMP} / \mathrm{g}$ e E.coli entre 0 e $4,6 \times 10^{3}$ $\mathrm{NMP} / \mathrm{g}$ sendo que $24,6 \%$ das amostras foram classificadas como em desacordo com a legislação sanitária brasileira (PRADO et al. 2006). 
Em Campinas, São Paulo, foram analisadas 180 amostras de hortaliças minimamente processadas e, embora nenhuma delas tenha apresentado Salmonella spp., $52(28,3 \%)$ apresentaram contagens de E. coli acima de $100 \mathrm{UFC/g}$, sendo consideradas inadequadas de acordo com os parâmetros estabelecidos pela legislação brasileira, RDC12 de 2/1/2002 (SANTOS et al. 2006).

Em outros países, a qualidade das hortaliças minimamente processadas também vem sendo pesquisada. Como o trabalho de KANEKO et al. (1999), que realizaram uma pesquisa no Japão em 238 amostras para determinar o nivel de contaminação de hortaliças frescas prontas para consumo e hortaliças inteiras, antes de serem processadas em duas indústrias. Ainda que os autores tenham encontrado coliformes e outros contaminantes com elevada freqüência em amostras de produtos minimamente processados, não detectaram a presença de $L$. monocytogenes em nenhuma das amostras pesquisadas. Das 83 amostras positivas para coliformes, os autores isolaram apenas em três a bactéria $E$. coli. Segundo os autores, a baixa ocorrência do microrganismo é conseqüência da menor contaminação fecal das hortaliças inteiras no Japão do que a apontada nas pesquisas em países não-industrializados.

Na Venezuela, CURTIS et al. (2002) verificaram que em produtos minimamente processados - alface e dois tipos de saladas compostas - a porcentagem de amostras com E. coli era de mais de $30 \%$, considerando o NMP/g de 150 ou superior, e cerca de $70 \%$, considerando o NMP 3/g. A positividade das amostras para L. monocytogenes foi de $25 \%$. 
Segundo BRACKETT e SPLITTSTOESSER (2001), a detecção de coliformes fecais tem pouca ou nenhuma relação com a contaminação fecal das hortaliças, já que a maioria dos gêneros faz parte da microbiota presente nestes produtos.

A contaminação microbiológica verificada nas hortifrutícolas pode se dar nas diferentes fases da produção - do campo à mesa. Com relação à produção no campo e colheita, pode-se destacar o cultivo em solo contaminado ou com uso de adubação orgânica à base de composto nãotratado ou inadequadamente tratado; o emprego de água contaminada na irrigação, na aplicação de fungicidas e inseticidas ou no resfriamento póscolheita; a falta de higiene pessoal dos trabalhadores e de estrutura para higiene e deposição correta de dejetos; a manipulação inadequada como o uso de utensílios de corte, caixas de campo, veículos de transporte e gelo contaminados (BEUCHAT 2002).

Dentre os pontos críticos relacionados ao cultivo das matérias-primas hortifrutícolas, temos a irrigação com água contaminada por microrganismos patogênicos. SOLOMON et al. (2003) realizaram um estudo experimental em que demonstraram que com uma única exposição de alface à irrigação com água contaminada por E. coli $0157: \mathrm{H} 7$, o microrganismo persistia viável por dezesseis dias.

O processamento inadequado dos produtos hortifrutícolas pode comprometer tanto a qualidade microbiológica como nutricional (BREENE 1994). A qualidade e a inocuidade das hortaliças minimamente processadas é muito dependente da matéria-prima que é utilizada em sua preparação. As 
pesquisas realizadas em hortaliças in natura demonstram que os problemas de contaminação no campo são bastante freqüentes em nosso meio.

NASCIMENTO et al. (2003) realizaram uma pesquisa sobre a qualidade higiênico-sanitária de frutas e hortaliças (alface crespa, morango, repolho e uva Itália) comercializadas no varejo em Campinas, São Paulo. O estudo demonstrou que somente as amostras de hortaliças apresentaram contagens de E. coli, sendo o índice de positividade de $25 \%$ (cinco positivas em 20 amostras) entre as hortaliças pesquisadas.

Também na cidade de Campinas foi realizado um estudo envolvendo 869 amostras de hortaliças de folha normalmente consumidas cruas no Brasil. As amostras eram provenientes de três fornecedores da Central de Abastecimento S.A. (CEASA) de Campinas. Em nenhuma das amostras foi constatada a presença de E. coli O157:H7 (SILVA et al. 2003).

Em um estudo realizado em Ribeirão Preto, São Paulo, foram analisadas hortaliças de folhas e água de irrigação provenientes de 129 hortas da cidade. Os pesquisadores concluíram que $17 \%$ das amostras das folhas continham coliformes fecais, $13,1 \%$ apresentaram contaminação por enteroparasitas e $3,1 \%$, resultado positivo para Salmonella spp. Foram consideradas inadequadas para produção segura de folhosas $20,1 \%$ das propriedades, sendo que em $7,7 \%$ desses locais foi constatada contaminação na água de irrigação. Os autores também alertam para a inexistência de controle sanitário da produção no campo e associam este fato com o alto índice de neurocisticercose diagnosticado na região (TAKAYANAGUI et al. 2000). 


\section{Microbiologia de hortifrutícolas}

A microflora das hortaliças e frutas é bastante variável e em geral localiza-se na sua superfície, sendo que as diferenças morfológicas e de atividade metabólica dos tecidos vegetais selecionam certas espécies ou grupos de microrganismos (BEUCHAT 2002). De acordo com o pH do produto, os frutos são mais suscetíveis aos microrganismos mais tolerantes à acidez do que as hortaliças de folha (GUNES et al. 1997).

Insetos, fungos, poeira e lesões mecânicas podem facilitar a penetração de microrganismos deteriorantes e bactérias patogênicas no interior dos tecidos vegetais. CALDWELL et al. (2003) demonstraram que nematóides de vida-livre podem veicular patógenos humanos para hortifrutícolas, como a Salmonella Poona usada no experimento.

As hortaliças e frutas são constituídos por tecidos vivos que continuam seus processos fisiológicos de respiração, amadurecimento e senescência mesmo depois da colheita (O'CONNOR-SHAW et al. 1996). Os danos físicos causados pela colheita e o processamento aumentam a atividade metabólica dos tecidos provocando maior taxa respiratória e produção de etileno, o que pode diminuir a vida útil das hortifrutícolas (ROLLE e CHISM 1987). A perda da integridade dos tecidos com liberação de exudato proveniente do corte no processamento mínimo proporciona um meio rico para o desenvolvimento de microrganismos deteriorantes e patogênicos, o que pode caracterizar um risco para a saúde dos consumidores (DAMASCENO et al. 2001). A composição química do 
exudato inclui minerais, açúcares, substâncias pectínicas e fenólicas, álcoois, hormônios, vitaminas e alcalóides (FRÖDER 2005).

As baixas temperaturas reduzem ao mesmo tempo a multiplicação microbiana e a taxa de respiração do tecido vegetal. Segundo FRANCIS et al. (1999), a temperatura é provavelmente o fator mais importante para a conservação dos produtos minimamente processados. Para a segurança microbiológica estes produtos devem ser mantidos e processados em temperaturas entre $0^{\circ} \mathrm{C}$ e $5^{\circ} \mathrm{C}$.

No levantamento realizado pelo MINISTÉRIO DA INTEGRAÇÃO NACIONAL (2002) em 300 (3\%) supermercados do Estado de São Paulo, foi constatado que a quantidade de lojas que possuíam equipamentos de exposição refrigerada para a comercialização de hortifrutícolas minimamente processadas era baixa, sendo maior nos hipermercados. Nas lojas classificadas como compactas, somente $5,4 \%$ possuíam equipamento refrigerado, $14,1 \%$ das convencionais, $17 \%$ das superlojas e $27,2 \%$ dos hipermercados.

Além da refrigeração, para a maioria das hortaliças e frutas a limpeza e lavagem com água clorada (desinfecção) podem ser as únicas técnicas de tratamento para a conservação. A transformação relativamente simples da hortifrutícola in natura em um produto pronto para o consumo pode ser realizada em plantas industriais altamente sofisticadas ou até em estruturas rudimentares. Como por exemplo, o descascamento com eliminação de partes não-aproveitáveis e o corte que podem ser realizados de forma manual. A maioria das hortifrutícolas minimamente processadas é embalada 
em sacos ou filmes plásticos com ou sem a introdução de gases. A embalagem modifica os níveis de umidade, $\mathrm{CO}_{2}$ e oxigênio, mas não é suficiente para garantir a manutenção do produto, sendo sempre necessário utilizar também a refrigeração (CHITARRA 1998, DAMASCENO et al. 2001).

Com as novas tecnologias de processamento e conservação de hortaliças e frutas, a vida de prateleira dos alimentos frescos é prolongada, o que possibilita a comercialização em áreas mais distantes dos pontos de produção e para um maior número de consumidores. O controle pelas agências governamentais é dificultado pela capacidade da indústria incorporar técnicas de produção e novos produtos em uma velocidade muito acima da capacidade dos órgãos reguladores legislar ou normatizar sobre o tema (LUCCHESI 2001).

Um exemplo disso é o consumo de alimentos típicos de outras culturas e de novos alimentos. Assim os pratos preparados com brotos de feijão, alfafa, arroz e trigo que são típicos da cozinha oriental se tornaram populares em muitas partes do mundo. Os brotos são germinados a partir de sementes mantidas molhadas durante três a sete dias em temperaturas de 20 a $25^{\circ} \mathrm{C}$, o que pode favorecer o desenvolvimento de microrganismos. Entre 1995 e 1998 ocorreram nove surtos devido ao consumo de brotos de alfafa contaminados por Salmonella spp e E. coli O157:H7 nos Estados Unidos (SHARMA 2002). O mesmo tipo de alimento causou um surto que atingiu 125 pessoas na Austrália (OZFOODNET 2006). Novos produtos e uma demanda crescente por alimentos com apelo fresco e nutritivo permitem 
o seu desenvolvimento e popularização em curtos espaços de tempo (SUSLOW et al. 2002).

A planta beneficiadora geralmente centraliza as matérias-primas de diversos produtores ou de centros de abastecimento como as CEASAs, dificultando a rastreabilidade e a garantia de que as boas práticas no campo foram seguidas.

Até o presente momento não há uma legislação específica para o controle da produção de hortifrutícolas minimamente processadas. O padrão microbiológico utilizado para os produtos prontos é a RDC 12 de 2 de janeiro de 2001. Segundo esse padrão, para frutas frescas in natura, preparadas (descascadas ou selecionadas ou fracionadas), sanificadas, refrigeradas ou congeladas destinadas ao consumo direto a tolerância máxima é de 500 UFC/g de coliformes a $45^{\circ} \mathrm{C}$; para as hortaliças frescas in natura sob as mesmas condições a tolerância máxima é de $100 \mathrm{UFC/g}$; e no caso de raizes e tubérculos in natura a tolerância máxima é de 1000 UFC/g. Para os três tipos de produtos o padrão determina a ausência de Salmonella spp em 25 gramas do alimento (MINISTÉRIO DA SAÚDE 2001).

\section{Epidemiologia}

A ocorrência de surtos de origem alimentar associados com o consumo de hortifrutícolas minimamente processadas é menos freqüente quando comparado com outros tipos de alimentos, mas o histórico dos casos registrados na literatura justifica o interesse no estudo, sobretudo por sua 
gravidade (POWELL et al. 2002, WACHTEL et al. 2002, BUCK et al. 2003, DeWAAL et al. 2006). No entanto o número de ocorrências vem aumentando, influenciado por diversas razões, como a mudança dos hábitos alimentares e das práticas agronômicas e o aumento do comércio internacional (SOLOMON et al. 2003).

Em 2006, nos Estados Unidos ocorreu um grande surto provocado pela ingestão de espinafre minimamente processado contaminado por $E$. coli 0157:H7. Três pessoas morreram e 204 ficaram doentes. Os investigadores puderam relacionar amostras ambientais de E. coli 0157:H7 de um campo de cultivo com a cepa que causou o surto usando a técnica de pulsed field gel eletroforesis. Entre os fatores ambientais de risco foram apontados a proximidade com porcos selvagens no campo de cultivo, e a proximidade do sistema de irrigação com fezes de bovinos e de animais silvestres (CALIFORNIA DEPARTMENT OF HEALTH SERVICES 2007a, 2007b).

Em 1981, no Canadá, um surto por consumo de salada de repolho cru provocou listeriose em sete adultos e em 34 perinatais, resultando em dezoito mortes. O repolho foi produzido por uma empresa regional que adquiriu o produto de uma fazenda em que havia ovinos com listeriose. A área de cultivo era adubada com fezes compostadas e não-compostadas dos ovinos (PRAZAK et al. 2002).

O número de surtos de infecções associadas com o consumo de produtos hortifrutícolas e suco de frutas não-pasteurizado tem aumentado nos últimos anos. Muitas razões têm sido propostas para justificar o aumento no número de casos, como a mudança nos hábitos alimentares, o maior 
consumo de produtos frescos e refeições fora de casa, mudanças nas formas de produção e processamento dos alimentos de origem vegetal, e emergência de patógenos que antes não eram relacionados com o consumo desses produtos (BUCK et al. 2003).

\section{Sanificação de hortifrutícolas}

Um dos pontos fundamentais da industrialização das hortifruticolas minimamente processadas é a sua sanificação. Em muitos casos, a água utilizada para a lavagem é reciclada por causa do alto volume de consumo e do custo para esse tipo de processamento (PIROVANI et al. 2004). A reciclagem da água é desejável também sob o ponto de vista ambiental.

As águas retiradas nas fases mais limpas do fluxo podem ser reintroduzidas nas fases mais sujas, mas este processo demanda a filtração e desinfecção da água. Muitos equipamentos de lavagem de hortifrutícolas podem utilizar a mesma água por longos periodos, expondo grande quantidade de alimentos à mesma água de imersão. A qualidade da água é um ponto crítico de controle capaz de amplificar um erro de gerenciamento de sanificação ou higiene durante a produção, colheita e pós-colheita.

Para garantir a inocuidade dos alimentos, o processo de sanificação deve destruir ou reduzir a niveis seguros os microrganismos patogênicos presentes. O método de escolha deve também reduzir os microrganismos deteriorantes para aumentar a vida de prateleira do alimento. 
Segundo VENKITANARAYANAN et al. (2002), o tratamento para sanificação necessita ser capaz de reduzir Salmonella spp, E.coli O157:H7 e L. monocytogenes em 3 e, preferencialmente, 5 logs de UFC, sem afetar as características sensoriais do alimento.

O processo de lavagem dos produtos hortifrutícolas pode remover as bactérias da superfície do tecido vegetal, mas uma parte dos microrganismos pode permanecer abrigada em dobras da epiderme e junções das células epidérmicas (ADAMS et al. 1989). Os patógenos também podem penetrar no tecido vegetal quando presentes em soluções com temperatura inferior à do vegetal ou ter sua penetração facilitada pelo emprego de detergentes na lavagem (BEUCHAT 2002).

Muitos trabalhos na literatura apresentam estudos sobre o uso de sanificantes em hortaliças visando a eliminação de patógenos humanos. São realizadas comparações entre sanificantes, tempos de contato, temperatura de aplicação, efeito da estocagem para diferentes produtos hortifrutícolas (ESCUDERO et al. 1999, YU et al. 2001, DELAQUIS et al. 2002, SHARMA et al. 2002, SUSLOW et al. 2002, BARI et al. 2002, DU et al. 2002, VENKITANARAYANAN et al. 2002, STAN e DAESCHEL 2003, SZABO et al. 2003, SANZ et al. 2003, KIM et al. 2003).

BEUCHAT et al. (2001) destacam a necessidade de padronizar as técnicas que são utilizadas nos estudos de eficácia de sanificantes em hortifrutícolas, embora admitam que um simples protocolo não poderá atender a todas as variabilidades existentes entre os vários tipos de produtos hortifrutícolas. 
Existem muitas limitações nos estudos experimentais que envolvem sobrevivência de microrganismos patogênicos. Por exemplo, a forma ideal de cultivo dos inóculos difere muito das condições de cultivo quando feito sobre os tecidos vegetais; substâncias presentes nos produtos de origem vegetal, próprias para a inibição de fitopatógenos, podem agir sobre os microrganismos do estudo. Outra variável de interferência na interpretação dos resultados é a possibilidade dos microrganismos penetrarem no interior do tecido vegetal durante o experimento. Os estudos que comparam população antes e depois da aplicação do sanificante em hortifrutícolas se deparam com a dificuldade em eliminar os microrganismos antes do teste, sem destruir o tecido. Dentre outras dificuldades, BEUCHAT et al. (2001) chamam a atenção para a forma de se reportar os resultados em unidades formadoras de colônia por gramas ou por centímetros quadrados, devido à grande diferença entre a área de superfície e peso das hortifrutícolas, que pode impossibilitar a transposição dos resultados para outros produtos.

Os estudos mostram que a capacidade de destruição dos microrganismos pelos sanificantes é limitada quando se utiliza condições de tratamento e inoculação realistas (SAPERS 2001). O processamento mínimo não assegura a ausência de microrganismos patogênicos e outras tecnologias necessitam ser empregadas para este fim (LANDGRAF e NUNES, 2006). Com a impossibilidade de se eliminar os microrganismos patogênicos no processamento, fica ressaltada a importância do controle dos produtos hortifrutícolas no campo. 
Os sanificantes mais comumente utilizados são à base de cloro, com concentração da solução de até 200 ppm (partes por milhão - mg/L ou mL/L) por 10 a 15 minutos (DAMASCENO et al. 2001). Para estimar a quantidade do sanificante na solução são usados testes colorimétricos (kits) ou fitas impregnadas quimicamente. Os testes existentes não separam a forma mais ativa de combate aos microrganismos, o ácido hipocloroso $(\mathrm{HOCl})$, da menos ativa, o ânion hipoclorito $\left(\mathrm{OCl}^{-}\right)$.

O hipoclorito de sódio, assim como o hipoclorito de cálcio, o dióxido de cloro, o ozônio e o peróxido de hidrogênio são oxidantes, isto é, são capazes de receber elétrons. A ação letal sobre as bactérias se dá pela transferência abrupta de elétrons da parede da célula bacteriana, com perda de suas funções vitais. Dependendo da condição oxidante da solução, a inativação celular ocorrerá somente após algum tempo.

A ação do hipoclorito de sódio é fortemente influenciada pelo $\mathrm{pH}$ da solução, pois com o aumento do $\mathrm{pH}$ o ácido hipocloroso se converte em ânion hipoclorito (STAN e DAESCHEL 2003). A concentração de cloro é reduzida também pela temperatura, luz e pela interação com resíduos de terra e matéria orgânica.

A ação dos desinfetantes pode se dar por três mecanismos (DANIEL 2001):

1. destruição ou danificação da organização estrutural da célula por meio da ação sobre a membrana celular, que gera disfunções na ação da membrana semipermeável ou combina-se com ácido ribonucléico do núcleo ou citoplasma; 
2. inativação ou competição por substratos de enzimas, o que leva a interferência no nível energético do metabolismo;

3. interferência nos processos de biossintese e crescimento devido a vários mecanismos como a síntese de proteínas, ácidos nucléicos, coenzimas ou células estruturais.

Os mecanismos preponderantes na desinfecção com os agentes oxidativos são a perda rápida de elétrons da parede celular com conseqüente ruptura, difusão do princípio ativo no interior da célula e interferência no processo celular. São pré-requisitos de um sanificante ter capacidade de oxidar moléculas biológicas e se difundir através da parede celular (DANIEL 2001).

O cloro e seus compostos interferem com a atividade respiratória, o transporte através da parede celular e o acido nucléico. O dióxido de cloro parece interferir com a sintese de proteínas e o ozônio ataca o ácido nucléico das bactérias.

A turbidez elevada da água também desempenha papel importante na redução da eficiência da desinfecção. Quando a turbidez se eleva acima de 1,0 uT parece haver menor inativação de coliformes quando os sanificantes são compostos de cloro. A matéria orgânica se adere aos microrganismos e os protegem da ação desinfetante ou reage com o sanificante formando subprodutos. Os compostos inorgânicos reagem com o sanificante, o pH e a temperatura interferem na dissociação química do desinfetante (DANIEL 2001). 
Os oxidantes fortes podem gerar subprodutos da desinfecção em função de sua toxidade. São conhecidos como resultantes da cloração da água os trihalometanos, ácidos halocéticos, halocetonas e outros compostos orgânicos halogenados. Aldeídos, cetonas, carbono orgânico assimilável e biodegradável associados ao uso do ozônio, do cloro e processos de oxidação avançada. Cloritos, cloratos resultantes do uso do dióxido de cloro exposto a luz solar e o bromato associado como o uso do ozônio. Dependendo da dose de hipoclorito na água, pode haver clorato em teores elevados (DANIEL 2001).

A reação entre o hipoclorito de sódio e a água ocorre segundo a equação:

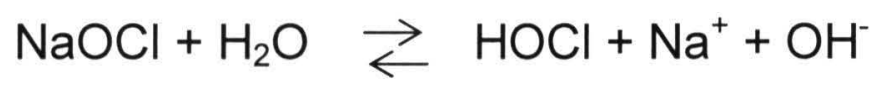

O hipoclorito de sódio se hidrolisa e forma o ácido hipocloroso $(\mathrm{HOCl})$. O efeito germicida do ácido hipocloroso é considerado maior que o do íon hipoclorito $\left(\mathrm{OCl}^{-}\right)$, que é resultado de sua dissociação do ácido hipocloroso, como descrito na equação abaixo:

$$
\mathrm{HOCl} \rightleftarrows \mathrm{H}^{+}+\mathrm{OCl}^{-}
$$

Abaixo do pH 6,5 não ocorre a dissociação do ácido hipocloroso e acima de $\mathrm{pH} 8,5$ todo o ácido hipocloroso se dissocia em íon hipoclorito. $\mathrm{O}$ sódio pode continuar a geração de hipoclorito.

O dióxido de cloro não forma ácido hipocloroso em sua reação, reduzindo-se apenas em íon clorito, embora seja considerado um forte oxidante. Entre as vantagens destaca-se a baixa reatividade com a matéria orgânica, a não conversão para clorofenóis que resultam em mau sabor e 
odor, e a inabilidade de reagir com a amônia para produzir cloraminas e trihalometanos (DU et al. 2002).

Os compostos orgânicos de cloro, como o dicloro isocianurato de sódio $\left(\mathrm{NaCl}_{2} \mathrm{C}_{3} \mathrm{~N}_{3} \mathrm{O}_{3}\right)$, comercialmente identificado como dicloro-Striazinatriona sódica, ao reagirem com a água também liberam o ácido hipocloroso, como se pode observar na reação:

$\mathrm{NaCl}_{2} \mathrm{C}_{3} \mathrm{~N}_{3} \mathrm{O}_{3}+2 \mathrm{H}_{2} \mathrm{O}=\mathrm{NaH}_{2} \mathrm{C}_{3} \mathrm{~N}_{3} \mathrm{O}_{3}+2 \mathrm{HOCl}$

Da mesma maneira que os demais compostos de cloro, seu potencial desinfetante deriva da formação do ácido hipocloroso. Não está totalmente elucidado o efeito do cianurato de sódio produzido na reação sobre a saúde humana.

\section{Potencial de óxido-redução}

A instabilidade do processo oxidativo necessita ser monitorada. $O$ potencial de óxido-redução (POR) é um parâmetro que tem sido pouco utilizado no controle das soluções sanificantes, mas oferece muitas vantagens. Qualquer valor de POR medido na água em $\mathrm{mV}$ revela o potencial oxidativo ou redutivo da solução, independentemente do tipo de desinfetante utilizado (ROJO 2002). O POR não indica a quantidade do sanificante presente, mas sua capacidade em agir sobre os microrganismos (SUSLOW 2004).

A água é considerada neutra, mas como possui oxigênio dissolvido é também um oxidante fraco. O POR da água é de 200 a $300 \mathrm{mV}$. Quando é 
acrescida uma substância oxidante, o POR sobe além de $300 \mathrm{mV}$. Quando a solução contém substâncias redutoras como o bissulfito de sódio, metabissulfito e o dióxido de enxofre, o POR tende a ser inferior a $200 \mathrm{mV}$.

Segundo SAPERS (2001), o controle da eficácia da sanificação com hipoclorito de sódio depende do controle do $\mathrm{pH}$ e da manutenção do POR em 650 a 700 mV. Com relação ao pH, SUSLOW (2004) argumenta que o controle do cloro livre por meio de fitas de papel e testes colorimétricos pode levar a falsa idéia de que uma solução está adequada para destruir microrganismos patogênicos por não diferenciar o ácido hipocloroso do íon hipoclorito. Assim, uma solução com pH 8,5 - em que somente $15 \%$ do cloro livre é representado pela fração mais reativa, o ácido hipocloroso - conterá a mesma quantidade de cloro livre de uma outra solução com pH 7,5 em que o ácido hipocloroso representa $50 \%$ do cloro livre. Se por outro lado o controle for realizado com base no POR, independentemente do $\mathrm{pH}$, vai-se buscar a faixa de milivolts estabelecida, mas talvez seja necessário utilizar muito mais hipoclorito de sódio ou outro sanificante para atingi-la em um pH inadequado, o que também não é interessante devido aos resíduos e ao custo. Visto por este lado, o controle conjunto do POR e pH pode maximizar o efeito do sanificante e racionalizar o seu uso.

Para manter $\circ \mathrm{pH}$ da solução sanificante em torno de 6,5 são utilizados ácidos de grau alimentar, mas há muitas evidências que sugerem que o ácido cítrico interfere na ação letal do ácido hipocloroso na faixa de 650 a 700 mV, devendo-se utilizar ácidos inorgânicos (SUSLOW 2004). O autor também considera como limitado o uso do POR quando o sanificante é 
o peróxido de hidrogênio, o ácido peroxiacético ou o ozônio. Este último considerando o uso em soluções com turbidez moderada, pois adequa-se bem para monitorar o ozônio em águas limpas.

SUSLOW (2004) apresenta resultados de diferentes testes relacionando a resistência de alguns microrganismos patogênicos para o homem e do indicador coliforme termotolerante de acordo com o tempo de contato e o POR da solução. Os dados são um resumo dos resultados de várias simulações de laboratório e estudos de revisão comerciais de resfriadores de água e estão sumarizados na tabela 1. De acordo com os dados apresentados, o indicador coliforme tolerante é mais resistente do que os microrganismos patogênicos E. coli O157:H7 e Salmonella spp e similar à L. monocytogenes na faixa de $665 \mathrm{mV}$.

Tabela 1 - Tempo de resistência de E. coli O157:H7, Salmonella spp, Listeria monocytogenes e coliforme termotolerante em três faixas de potencial de oxido-redução.

\begin{tabular}{|c|c|c|c|}
\hline \multirow[b]{2}{*}{ Patógeno / indicador } & \multicolumn{3}{|c|}{$\begin{array}{c}\text { Resistência em segundos (s) ou horas (h) ao } \\
\text { POR (mV) }\end{array}$} \\
\hline & $<485 \mathrm{mV}$ & $>550 \mathrm{e}<620 \mathrm{mV}$ & $>665 \mathrm{mV}$ \\
\hline E. coli O157:H7 & $>300 \mathrm{~s}$ & $<60 \mathrm{~s}$ & $<10 \mathrm{~s}$ \\
\hline Salmonella spp & $>300 \mathrm{~s}$ & $>300 \mathrm{~s}$ & $<20 s$ \\
\hline Listeria monocytogenes & $>300 \mathrm{~s}$ & $>300 \mathrm{~s}$ & $<30 \mathrm{~s}$ \\
\hline Coliforme termotolerante & $>48 \mathrm{~h}$ & $>48 \mathrm{~h}$ & $<30 \mathrm{~s}$ \\
\hline
\end{tabular}

Fonte: Suslow 2004. 
Há poucos dados detalhados na literatura sobre o POR para eliminação de microrganismos de interesse para preservar a qualidade póscolheita, vida de prateleira e inocuidade alimentar.

\section{Medidores de POR}

Um medidor de POR é semelhante a um medidor de $\mathrm{pH}$ que utiliza no eletrodo prata, ouro ou mais comumente platina. Os medidores de POR medem a voltagem gerada quando um sensor é colocado na água na presença de um agente oxidativo ou redutor. O eletrodo de platina transfere reversivelmente seus elétrons ao agente oxidativo. Uma voltagem é gerada. Quanto maior é a quantidade de oxidante disponível, maior a voltagem comparativa gerada (PULSE INSTRUMENTS 2005).

Segundo o fabricante Pulse Instruments há modelos de tamanho e custo reduzidos em que o medidor e o eletrodo são integrados. Apresentam uma expectativa de uso de um ano com boa confiabilidade da medição de POR. Os modelos classificados como portáteis fornecem um alto grau de confiabilidade. Os eletrodos podem ser internos ou externos ligados por cabos recolocáveis. A expectativa de uso do eletrodo é de um a dois anos e muitos modelos medem conjuntamente $\mathrm{pH}$ e temperatura. $\mathrm{O}$ mercado dispõe também de medidores de POR fixos para medição contínua. Alguns modelos

podem alimentar um sistema automático de reposição de sanificante e estabelecer um registro histórico de toda a produção. Todos os eletrodos de 
POR e de pH necessitam de limpeza e calibração periódica para garantir a confiabilidade das leituras.

Tendo em vista o que foi exposto e procurando contribuir para o enriquecimento do tema, planejou-se a presente investigação a fim de atingir os objetivos que são apresentados a seguir. 
1. Estabelecer por meio da demanda química de oxigênio (DQO) a quantificação da matéria orgânica presente na água de imersões padronizadas de alface americana.

2. Avaliar a interferência da matéria orgânica e do uso repetido das soluções sanificantes na ação do dióxido de cloro estabilizado da marca comercial Tecsaclor®, hipoclorito de sódio marca comercial Virex Plus FLV 2\%® e dicloro-S-triazinatriona sódica diidratada da marca comercial Sumaveg® .

3. Avaliar a viabilidade do uso dos medidores portáteis de POR como um instrumento de controle em processo da fase de sanificação de hortifrutícolas para a indústria de minimamente processados e para os órgãos reguladores. 


\section{Material}

\subsection{Amostras vegetais}

Para o preparo das imersões e estudo da demanda química de oxigênio (DQO) foi utilizada alface americana (Lactuca sativa L) de cultivo convencional, adquirida no mercado embalada, com data de colheita de no máximo dois dias antes do início dos testes. Os testes foram distribuídos ao longo do período de novembro 2005 a janeiro 2007, portanto incluindo alfaces da produção agrícola de verão e de inverno.

1.2 Cepa padrão Escherichia coli ATCC 11229

A cepa do estudo foi adquirida liofilizada a partir da coleção de culturas do Instituto Adolfo Lutz de São Paulo (IAL) - Seção de Coleção de Culturas (E. coli ATCC 11229, lote 07/06).

\subsection{Sanificantes}

$\mathrm{Na}$ realização dos testes de eficácia antimicrobiana contra E. coli ATCC 11229 foram utilizados os seguintes sanificantes, adquiridos em local indicado pelos fabricantes para venda direta ao consumidor: 
- hipoclorito de sódio diluído a $200 \mathrm{mg} / \mathrm{L}$ a partir do produto comercial Virex Plus FLV $2 \% ®$ da empresa JonhsonDiversey;

- dióxido de cloro estabilizado diluído a $1250 \mathrm{~mL} / \mathrm{L}$ a partir do produto comercial Tecsaclor $\$$ \% da empresa SerQuimico;

- dicloro-S-triazinatriona sódica diidratada diluído a $200 \mathrm{mg} / \mathrm{L}$ a partir do produto comercial Sumaveg ${ }^{\circledR}$ da empresa JonhsonDiversey.

\section{Métodos}

\subsection{Preparo das imersões da alface americana}

Após o descarte das folhas mais externas e separação do talo, a alface americana foi lavada em água potável corrente, enxaguada com água Milli-Q e picada no laboratório em porções de aproximadamente $25 \mathrm{~cm}^{2}$, com auxílio de molde com $5 \mathrm{~cm}$ de altura por $5 \mathrm{~cm}$ de largura e utilizando lâmina afiada.

Os cortes de alface americana foram então pesados e imersos em água nas proporções de $0 \mathrm{~g}: 20 \mathrm{~mL}$ (sem imersão), $1 \mathrm{~g}: 20 \mathrm{~mL}\left(1^{\text {a }}\right.$

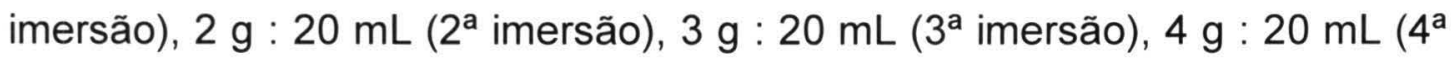
imersão), $5 \mathrm{~g}: 20 \mathrm{~mL}$ (5a imersão), $6 \mathrm{~g}: 20 \mathrm{~mL}$ (6 ${ }^{\mathrm{a}}$ imersão), $7 \mathrm{~g}: 20 \mathrm{~mL}$ (7 imersão) e $8 \mathrm{~g}: 20 \mathrm{~mL}$ ( $8^{\mathrm{a}}$ imersão). Todas as imersões foram preparadas com água Milli-Q para garantir a redução de contaminantes orgânicos e inorgânicos que pudessem interferir na reação. 
Em um frasco principal contendo água Milli-Q, uma porção de alface cortada foi agitada manualmente por meio de 25 movimentos verticais vigorosos seguidos de repouso por 10 minutos. Após esse período os cortes de alface foram removidos e parte da água da imersão $(50 \mathrm{~mL})$ destinada à análise da demanda química de oxigênio e ou testes de eficácia dos sanificantes. Neste último caso, a água da imersão removida (100 mL) foi autoclavada a $121^{\circ} \mathrm{C}$ por 20 minutos e mantida a $4^{\circ} \mathrm{C}$ em frasco tampado até o momento do uso. Uma nova porção de alface cortada foi adicionada à água restante do frasco principal de acordo com a proporção água/alface estabelecida e o procedimento repetido sucessivamente até a oitava imersão.

2.2 Determinação da demanda química de oxigênio (DQO), método do refluxo aberto segundo GREENBERG et al. 1992

A uma fração de $50 \mathrm{~mL}$ de material, de cada uma das imersões de alface americana, foi adicionada uma solução padrão de dicromato de potássio $\left(\mathrm{K}_{2} \mathrm{Cr}_{2} \mathrm{O}_{7}\right) \quad 0,0417 \mathrm{M}$ e solução de ácido sulfúrico concentrado contendo sulfato de prata $\left(\mathrm{Ag}_{2} \mathrm{SO}_{4}\right)$. Após homogeneização as amostras foram aquecidas em digestor a $150+/-2^{\circ} \mathrm{C}$ por 2 horas.

Após o resfriamento, o dicromato de potássio não-reduzido foi titulado com sulfato de amônia ferroso $0,025 \mathrm{M}$ para indicar a quantidade de dicromato de potássio consumido, a matéria orgânica foi calculada em 
termos de oxigênio equivalente e os resultados foram expressos em $\mathrm{mg}$ $\mathrm{O}^{2} / \mathrm{L}$.

Foram realizados dez testes de DQO das imersões de alface americana nas proporções de $0 \mathrm{~g}: 20 \mathrm{~mL}$ (sem imersão), $1 \mathrm{~g}: 20 \mathrm{~mL}$ (1 ${ }^{\text {a }}$

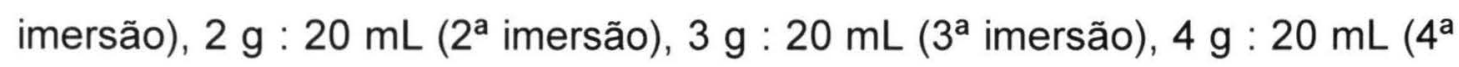
imersão) e mais dois testes das imersões de alface americana nas proporções de $5 \mathrm{~g}: 20 \mathrm{~mL}$ (5a imersão), $6 \mathrm{~g}: 20 \mathrm{~mL}$ (6a imersão), $7 \mathrm{~g}: 20 \mathrm{~mL}$ ( $7^{\mathrm{a}}$ imersão) e $8 \mathrm{~g}: 20 \mathrm{~mL}$ ( $8^{\mathrm{a}}$ imersão) para o cálculo da DQO média das imersões padronizadas.

\subsection{Preparo do inóculo}

A cultura de E. coli ATCC 11229 foi reativada segundo a orientação fornecida pelo IAL.

Após incubação em caldo Luria-Bertani por 20 a 24 horas a $37^{\circ} \mathrm{C}$, a cepa de E. coli foi então inoculada em ágar nutriente. Esse último procedimento foi realizado por três dias consecutivos.

No quarto dia as colônias foram retiradas após diluição com $1 \mathrm{~mL}$ de solução fisiológica esterilizada e transferidas para tubo de fundo redondo com $4 \mathrm{~mL}$ de solução fisiológica estéril. A mistura foi centrifugada a 4000 $\mathrm{rpm} / 10 \min$ a $4^{\circ} \mathrm{C}$.

O sobrenadante resultante da centrifugação foi desprezado, o sedimento suspendido e ajustado em espectrofotômetro no comprimento de 
onda de $650 \mathrm{~nm}$ para $92 \%$ de transmissão de luz, correspondendo a $2 \mathrm{x}$ $10^{8} \mathrm{UFC} / \mathrm{mL}$ (TOMASINO 2005).

O ajuste do inóculo foi realizado pouco antes do início dos ensaios com as imersões e mantido a $4^{\circ} \mathrm{C}$ até o final do experimento. A contagem de células viáveis foi efetuada no início do ensaio, assim como no final por meio de diluição seriada e semeadura em placas contendo ágar Luria-Bertani incubadas a $37^{\circ} \mathrm{C}$ por 24 horas.

\subsection{Enumeração de células de E. coli}

As células viáveis de $E$. coli foram enumeradas a partir de $1 \mathrm{~mL}$ de cada diluição seriada em solução salina $0,85 \%$ distribuída pela técnica de espalhamento sobre placas de ágar Luria-Bertani incubadas a $37^{\circ} \mathrm{C}$ por 24 horas. Os resultados foram expressos em unidades formadoras de colônia por mililitro (UFC/mL).

\subsection{Preparo das soluções sanificantes}

Os sanificantes foram diluídos diretamente na água das imersões contendo matéria orgânica proveniente dos cortes de alface americana. As quantidades dos produtos sanificantes utilizadas nas soluções dos testes foram estabelecidas de acordo com as instruções contidas nos rótulos dos produtos comerciais. Em todos os testes foram utilizados sanificantes provenientes de embalagens invioladas e dentro do prazo de validade. 
O sanificante dióxido de cloro estabilizado do "ensaio 1" e o hipoclorito de sódio do "ensaio 2" foram misturados nas imersões no momento do uso. Para avaliar a interferência do tempo de preparo da solução na eficácia do sanificante, o "ensaio 3" com hipoclorito de sódio e o "ensaio 4" com dicloroS-triazinatriona sódica diidratada foram realizados com soluções preparadas antes do uso.

Neste caso, as diluições dos sanificantes foram preparadas antes da mistura com o inóculo, com um espaço de 30 minutos entre cada imersão. Desta maneira o controle (água sem imersão) foi inoculado imediatamente após o preparo. A primeira imersão, que representa a primeira utilização da solução, só foi inoculada após 30 minutos do preparo da solução. A segunda, após 60 minutos, e assim sucessivamente até que a solução da oitava imersão estivesse "envelhecida" por 240 minutos, antes da mistura com o inóculo.

2.6 Teste do medidor de potencial de óxido-redução (POR) nas soluções sanificantes

As medições do potencial de óxido-redução foram realizadas com a introdução do sensor de POR do equipamento Tracer Pocketester com hastes intercambiáveis (Policontrol Instrumentos de Controle Ambiental Ind. e Com. Ltda.) nas imersões com os sanificantes testados. Os dados foram registrados durante os testes nos intervalos de 2, 5, 10 e 15 minutos de 
contato do inóculo com água da imersão contendo sanificante e matéria orgânica.

As leituras foram realizadas pela introdução do sensor em uma porção de aproximadamente $20 \mathrm{~mL}$ da água das imersões retirada dos frascos originais e transferida para frasco Erlemeyr limpo e seco.

O tempo de contato do sensor com a solução durante a medição foi padronizado em 30 segundos para o registro do valor em mV. Foi considerada aceitável uma oscilação de até $25 \mathrm{mV}$ no momento da leitura. Nesse caso foi registrado o valor mediano da faixa de variação.

Entre uma medição e outra o sensor foi lavado cuidadosamente em água corrente da torneira e depois enxaguado em água Milli-Q. Um cuidado especial foi tomado durante a lavagem para remover bolhas de ar junto à cavidade próxima ao sensor de platina.

Os cuidados de uso e calibração foram seguidos conforme o manual do equipamento (LaMotte 2005).

2.7 Teste de eficácia dos sanificantes em presença de matéria orgânica proveniente de imersões sucessivas de alface americana

Os frascos contendo água Milli-Q e a matéria orgânica das imersões esterilizadas em autoclave e mantidas refrigerados foram abertas em fluxo laminar para introdução do sanificante e do inóculo de E. coli. Após agitação manual e dos tempos de contato de 2, 5, 10 e 15 minutos, alíquotas de $1 \mathrm{~mL}$ foram transferidas para diluição seriada de base dez, sendo que apenas o 
primeiro tubo continha $9 \mathrm{~mL}$ de solução de tiossulfato de sódio. Após a homogeneização, $0,1 \mathrm{~mL}$ de cada diluição foi semeado pelo método do espalhamento em placas contendo meio Luria-Bertani.

No "ensaio 1" com dióxido de cloro estabilizado as imersões foram mantidas em temperatura ambiente $\left(22^{\circ}\right.$ a $\left.24^{\circ} \mathrm{C}\right)$ e no "ensaio 2 ", "ensaio $3^{\prime \prime}$ e no "ensaio 4", os frascos contendo as imersões foram mantidos em gelo, com temperatura variando de $4^{\circ} \mathrm{C}$ a $8^{\circ} \mathrm{C}$.

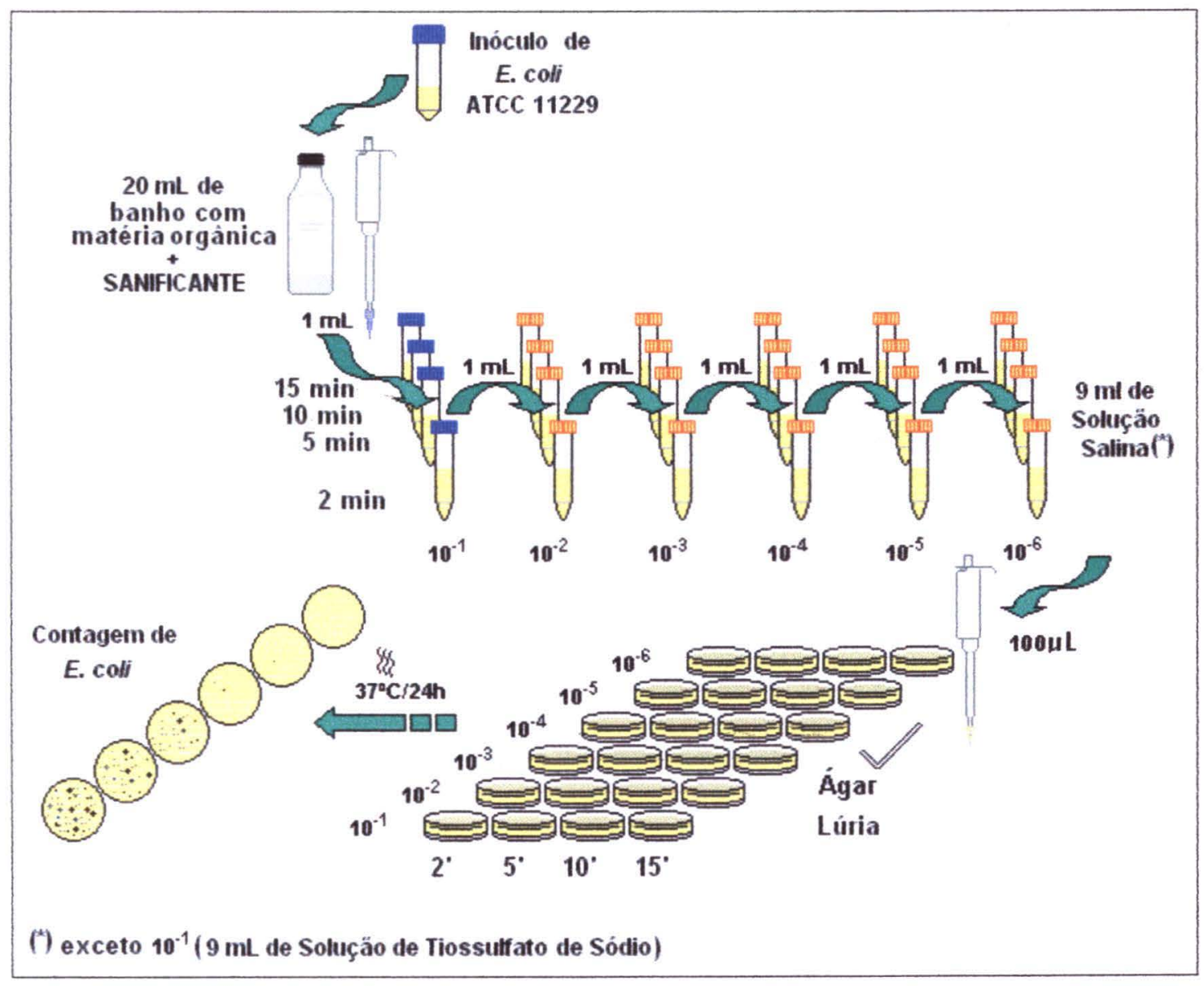

Figura 1 - Esquema dos testes de eficácia dos sanificantes em imersões contendo matéria orgânica. 


\section{Demanda química de oxigênio}

A quantidade de matéria orgânica suscetivel à oxidação foi mensurada através da técnica da demanda química de oxigênio (DQO) que indica a quantidade de matéria orgânica presente em uma solução. Os resultados obtidos das imersões de alface são apresentados na tabela 2 . O aumento do número de imersões e de gramas de alface em $20 \mathrm{~mL}$ de água causou em média a elevação da DQO de 5,7 para $337,5 \mathrm{mg} \mathrm{O} \mathrm{O}^{2} / \mathrm{L}$.

\section{Ensaio 1}

O potencial de óxido-redução (POR) foi medido durante as reações do sanificante com a água das imersões e o inóculo da bactéria. O POR em cada uma das imersões e tempos de contato do sanificante dióxido de cloro estabilizado com o inóculo de E. coli ATCC 11229 aparece descrito na tabela 3. O POR registrado neste ensaio manteve-se entre 417 e $549 \mathrm{mV}$.

Como pode ser verificado na figura 2, o POR do ensaio 1 apresentouse mais elevado a cada imersão, sendo que na terceira e quarta imersões os valores ficaram muito próximos. 
O aumento da matéria orgânica avaliada pela DQO média variando de $5,7 \mathrm{mg} \mathrm{O} / \mathrm{L}$ a $143,8 \mathrm{mg} \mathrm{O}_{2} / \mathrm{L}$ não reduziu o POR no ensaio 1 com dióxido de cloro estabilizado (figura 3).

\section{Ensaio 2}

O POR do ensaio 2 manteve-se baixo em todo o teste, sendo registrados valores na faixa de 290 e $490 \mathrm{mV}$ (tabela 4). A sétima e oitava imersões apresentaram os valores mais baixos em todos os tempos de contato, como pode ser observado na figura 4. A partir da quarta imersão pode ser verificada a diminuição progressiva do POR ao mesmo tempo em que se elevava a DQO das imersões (figura 5).

\section{Ensaio 3}

O ensaio 3 apresenta os resultados do teste realizado com solução "envelhecida" de hipoclorito de sódio. Nessas condições, verificou-se a variação do POR de 316 a $566 \mathrm{mV}$, sendo que os valores mais elevados foram verificados nas primeiras imersões (tabela 5). A sétima e oitava imersões apresentaram o POR sempre abaixo de $400 \mathrm{mV}$ (figura 6), mas a partir da quarta imersão, o POR já decaía à medida que a DQO se elevava (figura 7). 


\section{Ensaio 4}

O ensaio 4 apresenta os resultados do teste realizado com a solução de dicloro-S-triazinatriona sódica diidratada (dicloro STSD) com a solução de sanificante "envelhecida" da mesma maneira que no ensaio 3. O POR verificado nesse ensaio permaneceu sempre acima de $700 \mathrm{mV}$, tendo sido registrada a variação de 768 a $877 \mathrm{mV}$ ao longo das imersões. Os valores de POR foram os mais elevados entre todos os ensaios e não apresentaram tendência de redução com a elevação da DQO (figura 9). A água sem imersão (controle) apresentou o mais baixo POR entre as imersões do dicloro STSD (figura 8).

\section{Eficácia dos sanificantes}

Nos testes microbiológicos não foram verificadas contagens quando o sanificante utilizado foi o dióxido de cloro e o dicloro STSD. Em ambos os casos a redução foi maior que 5 logs.

$\mathrm{Na}$ tabela 8 são apresentadas as contagens logarítmicas das reduções de microrganismos dos ensaios 2 e 3 (hipoclorito de sódio). Verificam-se reduções da ordem de 0,7 a 8,5 logs, sendo que a água sem imersão (controle) do ensaio 2 não registrou redução em relação ao inóculo. A representação gráfica das contagens de E. coli recuperadas após o contato com o sanificante são apresentadas nas figuras 10 e 11. Nota-se 
que o oitava imersão da solução "envelhecida" (ensaio 3) apresentou mais freqüentemente bactérias sobreviventes ao contato com o sanificante. 
Tabela 2 - Demanda química de oxigênio (DQO) em miligrama de oxigênio por litro ( $\mathrm{mg} \mathrm{O} / \mathrm{L}$ ) segundo número de imersões de alface americana em água Milli-Q.

Demanda Química de Oxigênio ( $\left.\mathrm{mg} \mathrm{O}^{2} / \mathrm{L}\right)$

Imersões e

gramas de alface americana: $\mathrm{mL}$ de água

\begin{tabular}{|c|c|c|c|c|c|c|c|c|c|}
\hline Amostra & $\begin{array}{c}\text { Sem } \\
\text { imersão } \\
\text { (controle) } \\
0: 20\end{array}$ & $\begin{array}{c}1^{a} \\
1 \cdot 20\end{array}$ & $\begin{array}{c}2^{\mathrm{a}} \\
2 \cdot 20\end{array}$ & $\begin{array}{c}3^{\mathrm{a}} \\
3 \cdot 20\end{array}$ & $\begin{array}{c}4^{a} \\
4 \cdot 20\end{array}$ & $\begin{array}{c}5^{a} \\
5: 20\end{array}$ & $\begin{array}{c}6^{a} \\
6 \cdot 20\end{array}$ & $\begin{array}{c}7^{a} \\
7: 20\end{array}$ & $\begin{array}{c}8^{a} \\
8: 20\end{array}$ \\
\hline & & $1: 20$ & $2: 20$ & $3: 20$ & & & & $7: 20$ & $8: 20$ \\
\hline
\end{tabular}

\begin{tabular}{|c|c|c|c|c|c|c|c|c|c|}
\hline$A$ & 0 & 24 & 59 & 98 & 150 & - & - & - & - \\
\hline B & 0 & 15 & 37 & 74 & 126 & - & - & - & - \\
\hline C & 0 & 31 & 51 & 90 & 145 & - & - & - & - \\
\hline D & 4 & 35 & 50 & 84 & 92 & - & - & - & - \\
\hline$E$ & 0 & 11 & 58 & 84 & 134 & - & - & - & - \\
\hline$F$ & 0 & 27 & 54 & 84 & 104 & - & - & - & - \\
\hline G & 15 & 43 & 78 & 128 & 132 & - & - & - & - \\
\hline $\mathrm{H}$ & 38 & 57 & 88 & 111 & 204 & - & - & - & - \\
\hline I & 0 & 57 & 77 & 114 & 233 & - & - & - & - \\
\hline$J$ & 0 & 29 & 49 & 73 & 118 & - & - & - & - \\
\hline $\mathrm{K}$ & - & - & - & - & - & 204 & 264 & 340 & 400 \\
\hline $\mathrm{L}$ & - & - & - & - & - & 167 & 211 & 251 & 275 \\
\hline \multirow[t]{2}{*}{ Média } & & & & & 143 & 185 & 237 & 295 & 337 \\
\hline & 5,7 & 32,9 & 60,1 & 94 & 8 & 5 & 5 & 5 & 5 \\
\hline \multicolumn{10}{|l|}{ Desvio } \\
\hline Padrão & 7,6 & 11,0 & 11,4 & 13,6 & 28,5 & 12,3 & 17,7 & 29,7 & 41,7 \\
\hline
\end{tabular}


Tabela 3 - Potencial de óxido-redução em milivolts $(\mathrm{mV})$ segundo o tempo de contato da cepa padrão $E$. coli com o sanificante dióxido de cloro estabilizado $\left(\mathrm{ClO}_{2}\right.$, Tecsaclor $\left.囚\right)$ nas diferentes proporções de alface americana por imersão em água, ensaio 1.

\begin{tabular}{|c|c|c|c|c|c|}
\hline \multirow{4}{*}{$\begin{array}{l}\text { ENSAIO } 1 \\
\text { Tempo de } \\
\text { contato E. coli } \\
\text { com dióxido de } \\
\text { cloro }\end{array}$} & \multicolumn{5}{|c|}{ Potencial de óxido-redução (mV) } \\
\hline & \multicolumn{5}{|c|}{$\begin{array}{c}\text { Imersões e } \\
\text { gramas de alface americana: } \mathrm{mL} \text { de água }\end{array}$} \\
\hline & $\begin{array}{l}\text { imersão } \\
\text { (controle) }\end{array}$ & $1^{a}$ & $2^{a}$ & $3^{a}$ & $4^{a}$ \\
\hline & $0: 20$ & $1: 20$ & $2: 20$ & $3: 20$ & $4: 20$ \\
\hline $2 \min$ & 417 & 458 & $\ldots$ & 500 & 513 \\
\hline $5 \mathrm{~min}$ & 450 & 504 & $\ldots$ & 529 & 529 \\
\hline $10 \mathrm{~min}$ & 497 & 529 & 537 & 549 & 544 \\
\hline
\end{tabular}




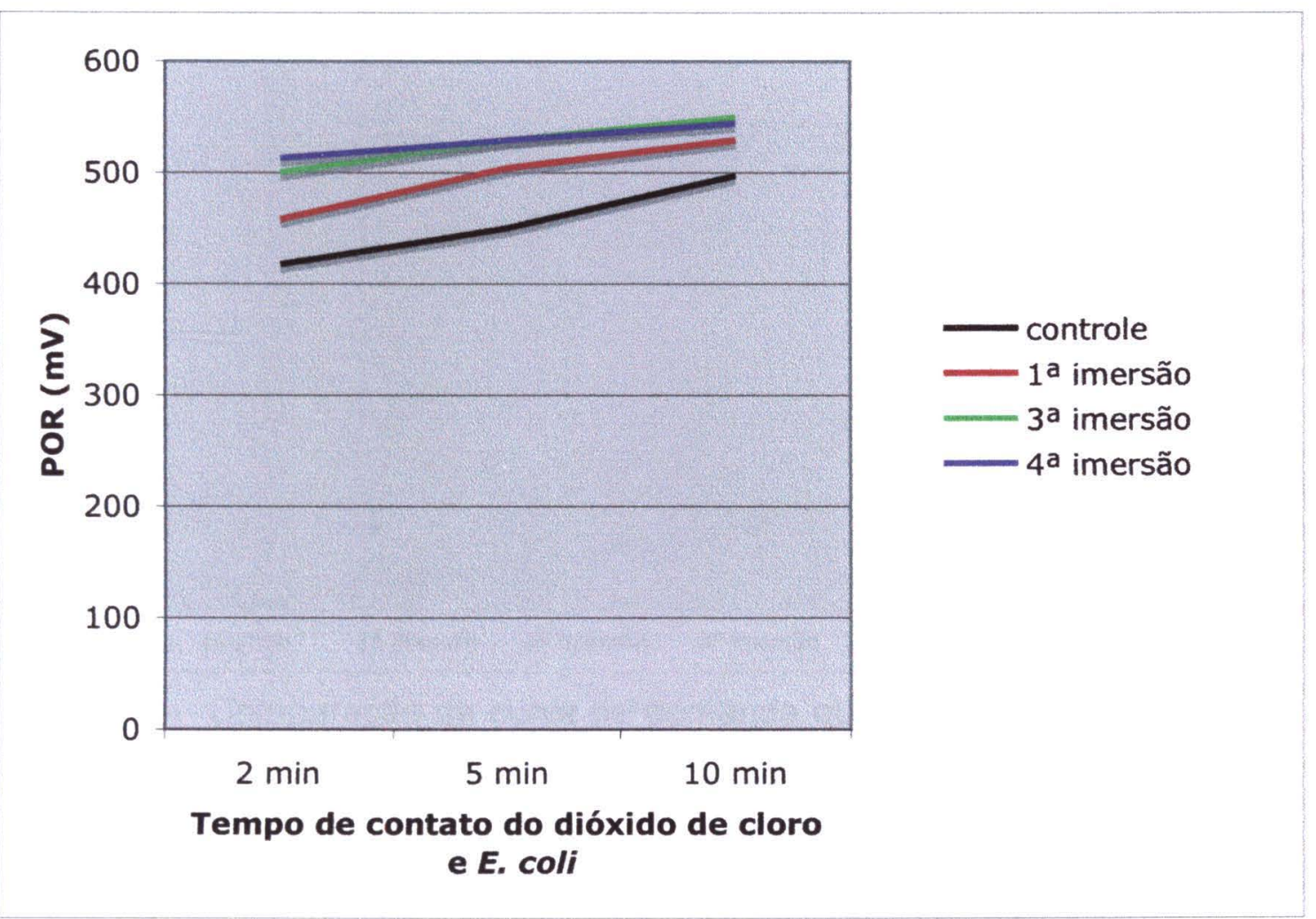

Figura 2 - Comportamento da água sem imersão (controle) e três imersões sucessivas* $^{*}$ contendo matéria orgânica proveniente dos cortes de alface americana** segundo o potencial de óxido-redução (POR) em milivolts $(\mathrm{mV})$, ao longo de 10 minutos de contato do inóculo de E. coli com dióxido de cloro estabilizado $\left(\mathrm{ClO}_{2}\right.$, Tecsaclor $\left.{ }^{\circledR}\right)$, ensaio 1.

* Eliminada a $2^{\mathrm{a}}$ imersão devido à falta de dados contínuos.

** Matéria orgânica proveniente dos cortes de alface americana nas proporções de $1 \mathrm{~g}: 20$ $\mathrm{mL}$ ( $1^{\mathrm{a}}$ imersão), $3 \mathrm{~g}: 20 \mathrm{~mL}$ ( $3^{\mathrm{a}}$ imersão) e $4 \mathrm{~g}: 20 \mathrm{~mL}$ ( $4^{\mathrm{a}}$ imersão). 


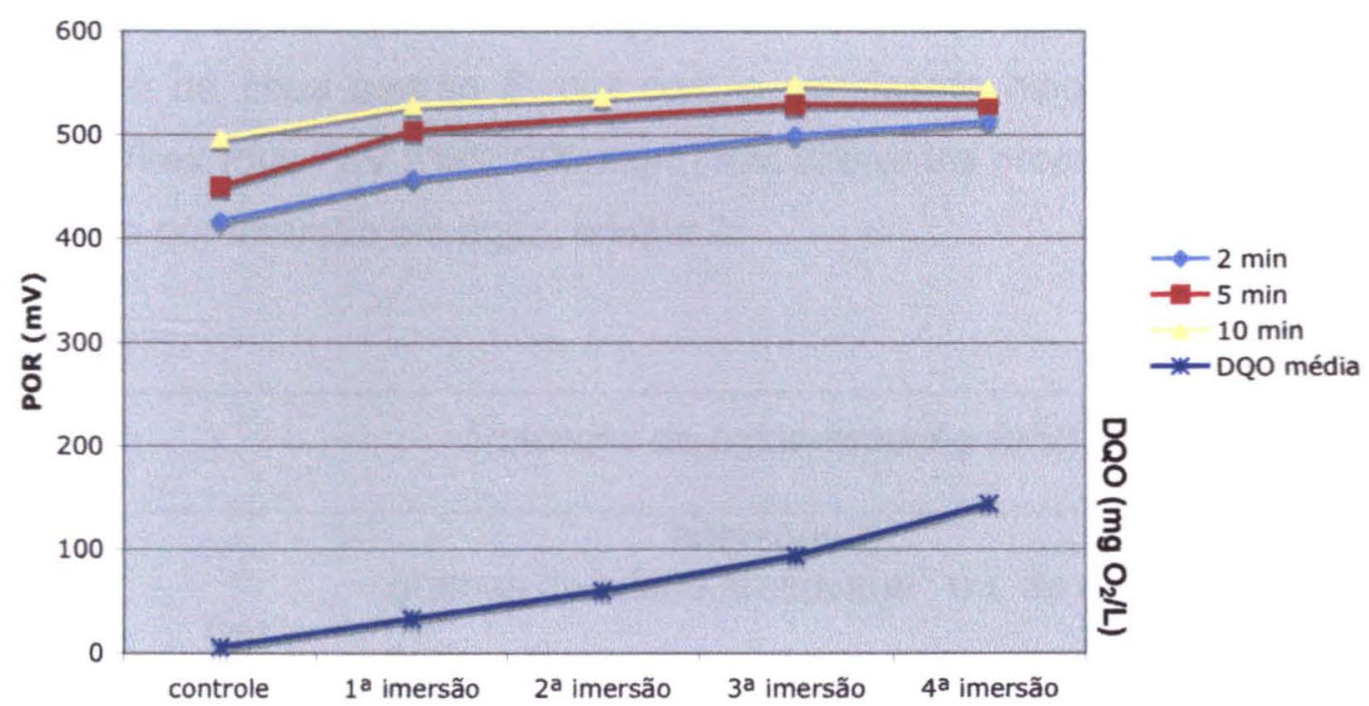

Figura 3 - Comparação da curva de demanda química de oxigênio (DQO) em $\mathrm{mg} \mathrm{O} / \mathrm{L}$ com o potencial de óxido-redução em milivolts $(\mathrm{mV})$ de três tempos de contato do dióxido de cloro estabilizado $\left(\mathrm{ClO}_{2}\right.$, Tecsaclorß) com o inóculo de $E$. coli em água sem imersão (controle) e mais quatro imersões sucessivas contendo matéria orgânica proveniente dos cortes de alface americana*, ensaio 1.

* Matéria orgânica proveniente dos cortes de alface americana nas proporções de $1 \mathrm{~g}: 20$ $\mathrm{mL}$ ( $1^{\mathrm{a}}$ imersão), $2 \mathrm{~g}: 20 \mathrm{~mL}$ ( ${ }^{\mathrm{a}}$ imersão), $3 \mathrm{~g}: 20 \mathrm{~mL}$ ( $3^{\mathrm{a}}$ imersão) e $4 \mathrm{~g}: 20 \mathrm{~mL}\left(4^{\mathrm{a}}\right.$ imersão). 
Tabela 4 - Potencial de óxido-redução em milivolts $(\mathrm{mV})$ segundo o tempo de contato da cepa padrão $E$. coli com o sanificante hipoclorito de sódio ( $\mathrm{NaClO}$, Virex Plus FLV 2\%®, 200 mg/L) nas diferentes proporções de alface americana por imersão em água, ensaio 2.

\begin{tabular}{|c|c|c|c|c|c|c|c|c|c|}
\hline \multirow{4}{*}{$\begin{array}{l}\text { ENSAIO } 2 \\
\text { Tempo de } \\
\text { contato E. } \\
\text { coli com } \\
\text { hipoclorito } \\
\text { de sódio }\end{array}$} & \multicolumn{9}{|c|}{ Potencial de óxido-redução (mV) } \\
\hline & \multicolumn{9}{|c|}{$\begin{array}{l}\text { Imersões e } \\
\text { gramas de alface americana : } \mathrm{mL} \text { de água }\end{array}$} \\
\hline & $\begin{array}{c}\text { Sem } \\
\text { imersão } \\
\text { (controle) }\end{array}$ & $1^{\mathrm{a}}$ & $2^{\mathrm{a}}$ & $3^{a}$ & $4^{a}$ & $5^{\mathrm{a}}$ & $6^{\mathrm{a}}$ & $7^{\mathrm{a}}$ & $8^{a}$ \\
\hline & $0: 20$ & $1: 20$ & $2: 20$ & $3: 20$ & $4: 20$ & $5: 20$ & $6: 20$ & $7: 20$ & $8: 20$ \\
\hline $2 \min$ & 417 & 399 & 425 & 400 & 425 & 399 & 402 & 320 & 290 \\
\hline $5 \mathrm{~min}$ & 441 & 457 & 449 & 442 & 470 & 420 & 410 & 355 & 327 \\
\hline $10 \mathrm{~min}$ & 472 & 470 & 470 & 463 & 483 & 447 & 447 & 379 & 337 \\
\hline $15 \mathrm{~min}$ & 490 & 488 & 488 & 474 & 490 & 453 & 453 & 372 & 340 \\
\hline
\end{tabular}




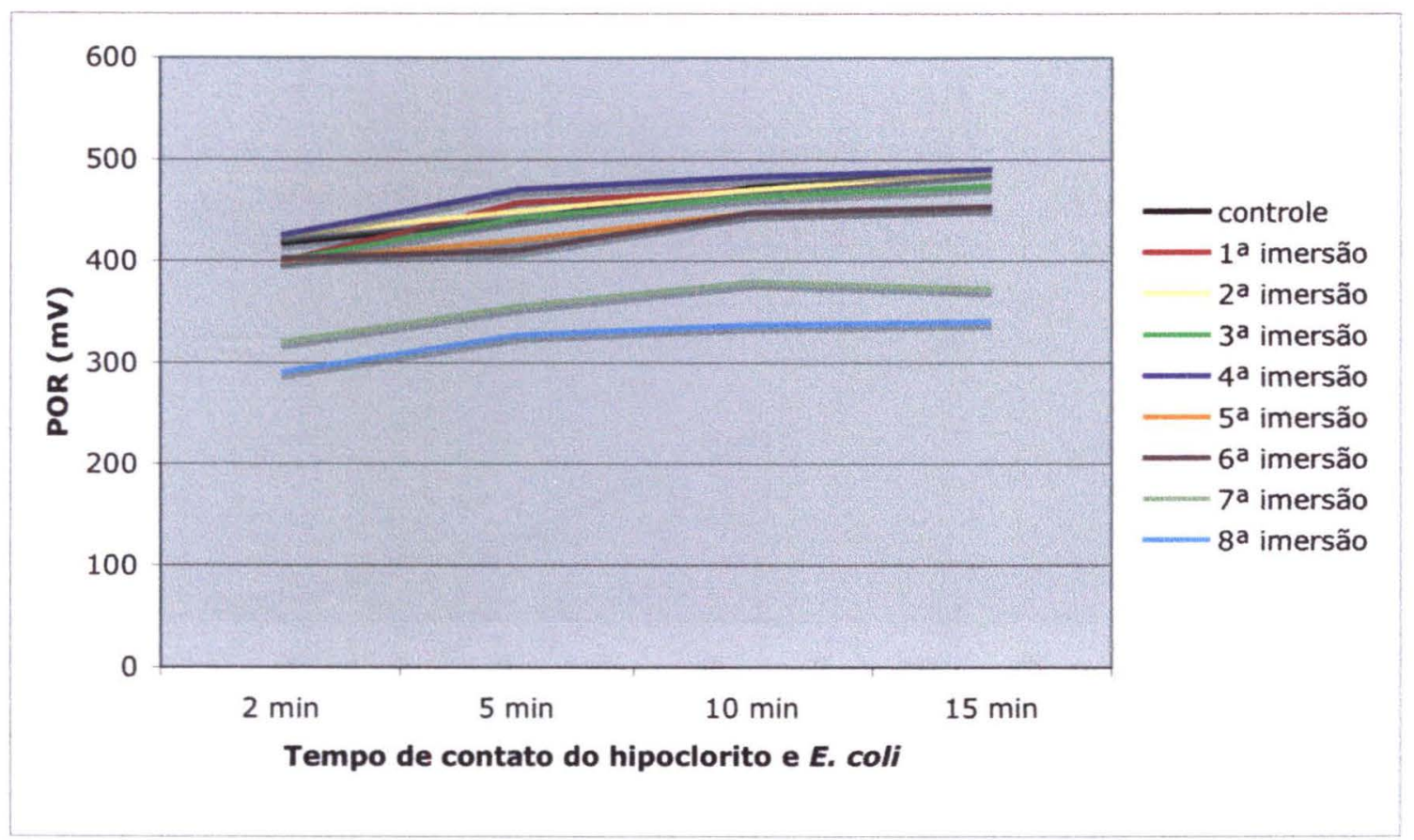

Figura 4 - Comportamento da água sem imersão (controle) e mais oito imersões sucessivas com matéria orgânica proveniente dos cortes de alface americana* segundo o potencial de óxido-redução (POR) em milivolts (mV), ao longo de 15 minutos de contato do inóculo de $E$. coli com o sanificante hipoclorito de sódio ( $\mathrm{NaClO}$, Virex Plus FLV 2\%®, 200 mg/L), ensaio 2.

* Matéria orgânica proveniente dos cortes de alface americana nas proporções de $1 \mathrm{~g}: 20$ $\mathrm{mL}$ ( ${ }^{\text {a }}$ imersão), $2 \mathrm{~g}: 20 \mathrm{~mL}$ ( $2^{\text {a }}$ imersão), $3 \mathrm{~g}: 20 \mathrm{~mL}$ (3 ${ }^{\mathrm{a}}$ imersão), $4 \mathrm{~g}: 20 \mathrm{~mL}\left(4^{\mathrm{a}}\right.$ imersão), $5 \mathrm{~g}: 20 \mathrm{~mL}$ ( $5^{\mathrm{a}}$ imersão), $6 \mathrm{~g}: 20 \mathrm{~mL}$ (6 $6^{\mathrm{a}}$ imersão), $7 \mathrm{~g}: 20 \mathrm{~mL}$ ( $7^{\mathrm{a}}$ imersão) e $8 \mathrm{~g}$ : $20 \mathrm{~mL}$ ( $8^{\mathrm{a}}$ imersão). 


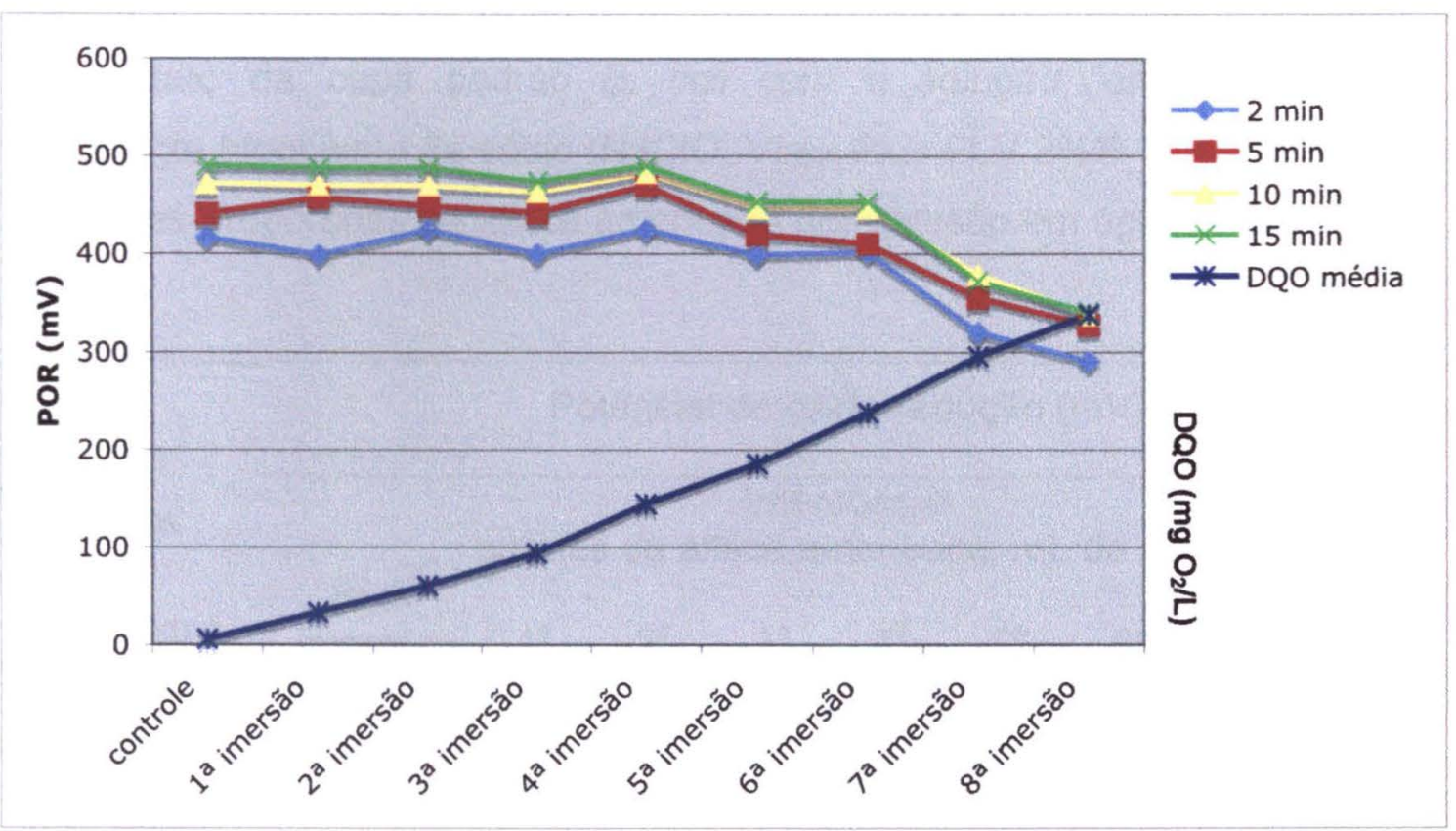

Figura 5 - Comparação da curva de demanda química de oxigênio (DQO) em $\mathrm{mg} \mathrm{O}^{2} / \mathrm{L}$ com o potencial de óxido-redução em milivolts $(\mathrm{mV})$ de quatro tempos de contato do hipoclorito de sódio ( $\mathrm{NaClO}$, Virex Plus FLV 2\%®, 200 $\mathrm{mg} / \mathrm{L}$ ) com o inóculo de $E$. coli em água sem imersão (controle) e mais oito imersões sucessivas contendo matéria orgânica proveniente dos cortes de alface americana*, ensaio 2 .

* Matéria orgânica proveniente dos cortes de alface americana nas proporções de $1 \mathrm{~g}: 20$ $\mathrm{mL}$ (1 ${ }^{\text {a }}$ imersão), $2 \mathrm{~g}: 20 \mathrm{~mL}$ (2 ${ }^{\mathrm{a}}$ imersão), $3 \mathrm{~g}: 20 \mathrm{~mL}$ (3 $3^{\mathrm{a}}$ imersão), $4 \mathrm{~g}: 20 \mathrm{~mL}\left(4^{\mathrm{a}}\right.$ imersão), $5 \mathrm{~g}: 20 \mathrm{~mL}$ ( $5^{\mathrm{a}}$ imersão), $6 \mathrm{~g}: 20 \mathrm{~mL}$ (6 $6^{\mathrm{a}}$ imersão), $7 \mathrm{~g}: 20 \mathrm{~mL}$ ( $7^{\mathrm{a}}$ imersão) e $8 \mathrm{~g}$ : $20 \mathrm{~mL}$ ( $8^{\mathrm{a}}$ imersão). 
Tabela 5 - Potencial de óxido-redução em milivolts $(\mathrm{mV})$ segundo o tempo de contato da cepa padrão E. coli com a solução "envelhecida" do sanificante hipoclorito de sódio ( $\mathrm{NaClO}$, Virex Plus FLV 2\%@, 200 mg/L) nas diferentes proporções de alface americana por imersão em água, ensaio 3.

\begin{tabular}{|c|c|c|c|c|c|c|c|c|c|}
\hline \multirow{2}{*}{$\begin{array}{l}\text { ENSAIO } 3 \\
\text { Tempo de } \\
\text { contato }\end{array}$} & \multicolumn{9}{|c|}{ Potencial de óxido-redução (mV) } \\
\hline & \multirow{2}{*}{$\begin{array}{c}\text { Sem } \\
\text { imersão } \\
\text { (controle) }\end{array}$} & \multicolumn{7}{|c|}{$\begin{array}{c}\text { Imersões e } \\
\text { gramas de alface americana: } \mathrm{mL} \text { de água }\end{array}$} & \multirow[b]{2}{*}{$8^{a}$} \\
\hline $\begin{array}{l}\text { E. coli com o } \\
\text { hipoclorito de } \\
\text { sódio }\end{array}$ & & $1^{\mathrm{a}}$ & $2^{a}$ & $3^{a}$ & $4^{a}$ & $5^{a}$ & $6^{a}$ & $7^{\mathrm{a}}$ & \\
\hline \multirow{3}{*}{$\begin{array}{l}\text { (solução } \\
\text { "envelhecida") }\end{array}$} & $0: 20$ & $1: 20$ & $2: 20$ & $3: 20$ & $4: 20$ & $5: 20$ & $6: 20$ & $7: 20$ & $8: 20$ \\
\hline & 0 & 30 & 60 & 90 & 120 & 150 & 180 & 210 & 240 \\
\hline & $\min$ & $\min$ & $\min$ & $\min$ & $\min$ & $\min$ & $\min$ & $\min$ & $\min$ \\
\hline $2 \min$ & 450 & 456 & 430 & 479 & 456 & 395 & 444 & 316 & 347 \\
\hline $5 \mathrm{~min}$ & 462 & 482 & 474 & 536 & 495 & 469 & 452 & 366 & 351 \\
\hline $10 \mathrm{~min}$ & 500 & 509 & 497 & 560 & 504 & 480 & 467 & 386 & 339 \\
\hline $15 \mathrm{~min}$ & 524 & 522 & 507 & 566 & 512 & 491 & 461 & 392 & 338 \\
\hline
\end{tabular}




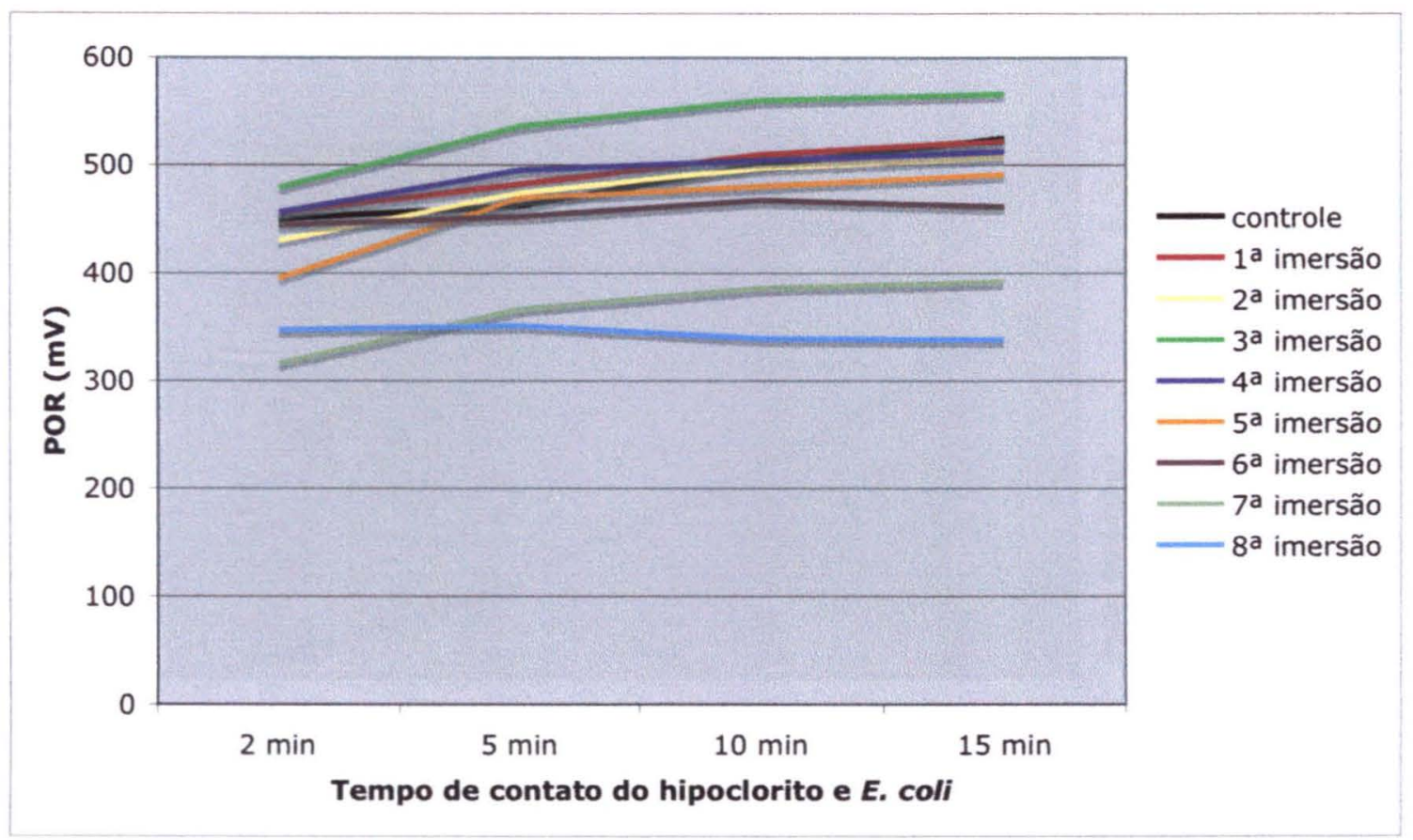

Figura 6 - Comportamento da água sem imersão (controle) e mais oito imersões sucessivas contendo matéria orgânica proveniente dos cortes de alface americana* segundo o potencial de óxido-redução (POR) em milivolts $(\mathrm{mV})$, ao longo de 15 minutos de contato do inóculo de $E$. coli com a solução "envelhecida"*夫 de hipoclorito de sódio ( $\mathrm{NaClO}$, Virex Plus FLV 2\%@, 200 $\mathrm{mg} / \mathrm{L})$, ensaio 3 .

* Matéria orgânica proveniente dos cortes de alface americana nas proporções de $1 \mathrm{~g}: 20$ $\mathrm{mL}\left(1^{\mathrm{a}}\right.$ imersão), $2 \mathrm{~g}: 20 \mathrm{~mL}$ ( $2^{\mathrm{a}}$ imersão), $3 \mathrm{~g}: 20 \mathrm{~mL}$ ( $3^{\mathrm{a}}$ imersão), $4 \mathrm{~g}: 20 \mathrm{~mL}\left(4^{\mathrm{a}}\right.$ imersão), $5 \mathrm{~g}: 20 \mathrm{~mL}$ ( $5^{\mathrm{a}}$ imersão), $6 \mathrm{~g}: 20 \mathrm{~mL}$ (6 $6^{\mathrm{a}}$ imersão), $7 \mathrm{~g}: 20 \mathrm{~mL}$ ( $7^{\mathrm{a}}$ imersão) e $8 \mathrm{~g}$ : $20 \mathrm{~mL}\left(8^{\mathrm{a}}\right.$ imersão).

** Solução preparada antes do uso: $30 \min 1^{a}$ imersão, $60 \min 2^{a}$ imersão, $90 \min 3^{\text {a }}$ imersão, $120 \operatorname{min~} 4^{\mathrm{a}}$ imersão, $150 \mathrm{~min} 5^{\mathrm{a}}$ imersão, $180 \min 6^{\mathrm{a}}$ imersão, $210 \mathrm{~min} 7^{\mathrm{a}}$ imersão, $240 \mathrm{~min} 8^{\mathrm{a}}$ imersão e solução recém-preparada para a água sem imersão (controle). 


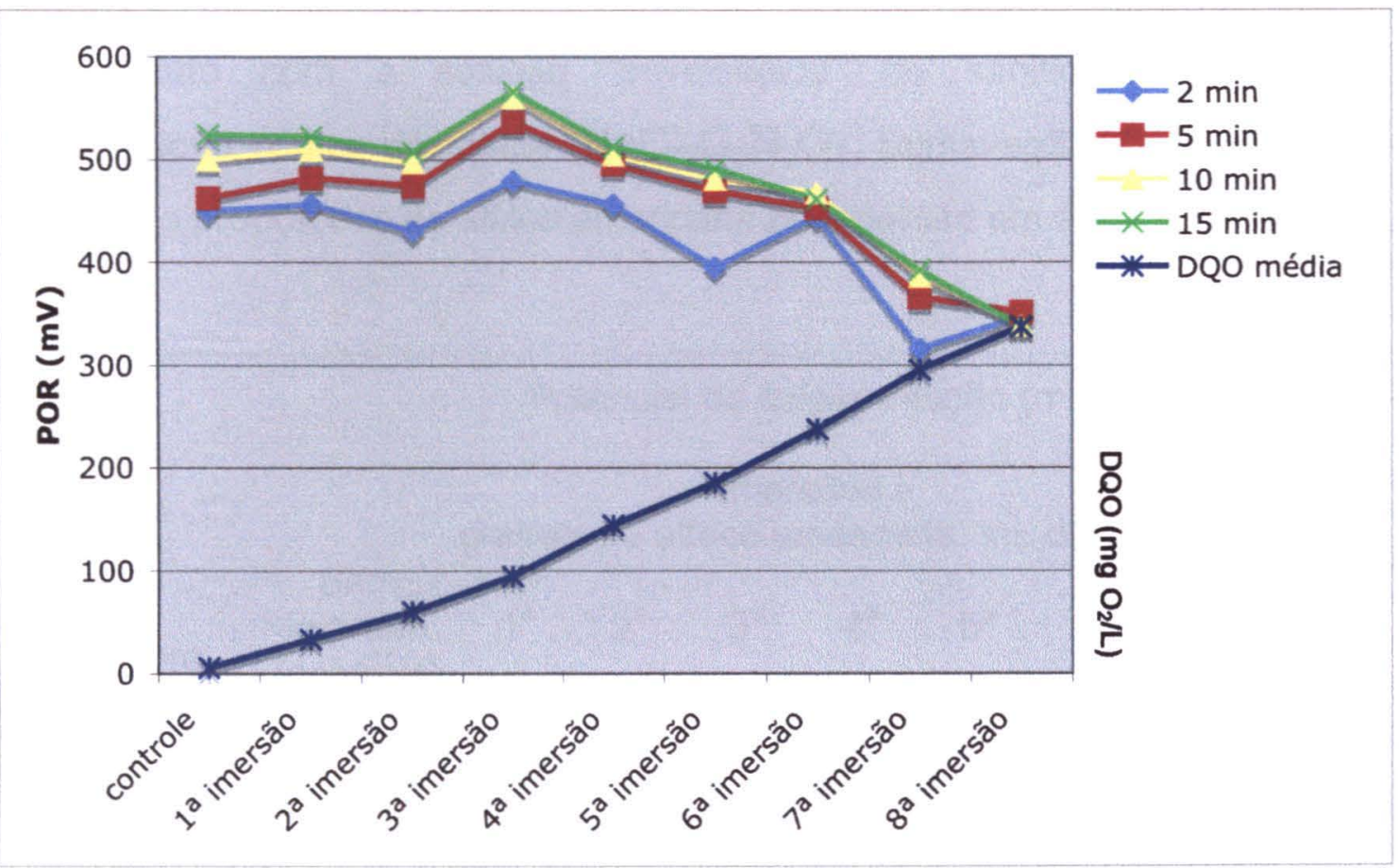

Figura 7 - Comparação da curva de demanda química de oxigênio (DQO) em $\mathrm{mg} \mathrm{O}^{2} / \mathrm{L}$ com o potencial de óxido-redução em milivolts $(\mathrm{mV})$ de quatro tempos de contato da solução "envelhecida"* de hipoclorito de sódio ( $\mathrm{NaClO}$, Virex Plus FLV $2 \% \Theta, 200 \mathrm{mg} / \mathrm{L}$ ) com o inóculo de $E$. coli em água sem imersão (controle) e mais oito imersões sucessivas contendo matéria orgânica proveniente dos cortes de alface americana**, ensaio 3 .

* Solução preparada antes do uso: $30 \min 1^{\text {a }}$ imersão, $60 \min 2^{\text {a }}$ imersão, $90 \min 3^{\text {a }}$ imersão, $120 \operatorname{min~} 4^{a}$ imersão, $150 \min 5^{a}$ imersão, $180 \min 6^{a}$ imersão, 210 min $7^{a}$ imersão, 240 min $8^{a}$ imersão e solução recém-preparada para a água sem imersão (controle).

** Matéria orgânica proveniente dos cortes de alface americana nas proporções de $1 \mathrm{~g}: 20$ $\mathrm{mL}$ (1 ${ }^{\mathrm{a}}$ imersão), $2 \mathrm{~g}: 20 \mathrm{~mL}$ ( ${ }^{\mathrm{a}}$ imersão), $3 \mathrm{~g}: 20 \mathrm{~mL}$ (3 $3^{\mathrm{a}}$ imersão), $4 \mathrm{~g}: 20 \mathrm{~mL}\left(4^{\mathrm{a}}\right.$ imersão), $5 \mathrm{~g}: 20 \mathrm{~mL}$ ( $5^{\mathrm{a}}$ imersão), $6 \mathrm{~g}: 20 \mathrm{~mL}$ (6 ${ }^{\mathrm{a}}$ imersão), $7 \mathrm{~g}: 20 \mathrm{~mL}$ ( $7^{\mathrm{a}}$ imersão) e $8 \mathrm{~g}$ : $20 \mathrm{~mL}$ ( $8^{\mathrm{a}}$ imersão). 
Tabela 6 - Potencial de óxido-redução em milivolts $(\mathrm{mV})$ segundo o tempo de contato com a solução "envelhecida" do sanificante dicloro-Striazinatriona sódica diidratada $\left(\mathrm{NaCl}_{2} \mathrm{C}_{3} \mathrm{~N}_{3} \mathrm{O}_{3}\right.$, Sumaveg ${ }^{\circledR}, 200 \mathrm{mg} / \mathrm{L}$ ) nas diferentes proporções de alface americana por imersão em água, ensaio 4.

\begin{tabular}{|c|c|c|c|c|c|c|c|c|c|}
\hline \multirow{6}{*}{$\begin{array}{l}\text { ENSAIO 4 } \\
\text { Tempo de } \\
\text { contato E. } \\
\text { coli } \\
\text { com dicloro } \\
\text { STSD* } \\
\text { (solução } \\
\text { "envelhecida") }\end{array}$} & \multicolumn{9}{|c|}{ Potencial de óxido-redução (mV) } \\
\hline & \multirow[b]{2}{*}{$\begin{array}{c}\text { Sem } \\
\text { imersão } \\
\text { (controle) }\end{array}$} & \multicolumn{7}{|c|}{$\begin{array}{c}\text { Imersões e } \\
\text { gramas de alface americana: } \mathrm{mL} \text { de água }\end{array}$} & \multirow[b]{2}{*}{$8^{a}$} \\
\hline & & $1^{a}$ & $2^{a}$ & $3^{a}$ & $4^{a}$ & $5^{a}$ & $6^{a}$ & $7^{\mathrm{a}}$ & \\
\hline & $0: 20$ & $1: 20$ & 2:20 & $3: 20$ & $4: 20$ & $5: 20$ & $6: 20$ & $7: 20$ & $8: 20$ \\
\hline & 0 & 30 & 60 & 90 & 120 & 150 & 180 & 210 & 240 \\
\hline & $\min$ & $\min$ & $\min$ & $\min$ & $\min$ & $\min$ & $\min$ & $\min$ & $\min$ \\
\hline $2 \min$ & 768 & 809 & 825 & 840 & 838 & 845 & 828 & - & 840 \\
\hline $5 \min$ & 795 & 811 & 838 & 843 & 829 & 855 & 845 & 859 & 877 \\
\hline $10 \mathrm{~min}$ & 805 & 816 & 838 & 816 & 842 & 860 & 849 & 860 & 876 \\
\hline $15 \mathrm{~min}$ & 809 & 827 & 833 & 816 & 850 & 835 & 853 & 870 & 873 \\
\hline
\end{tabular}

* Dicloro-S-triazinatriona sódica diidratada. 


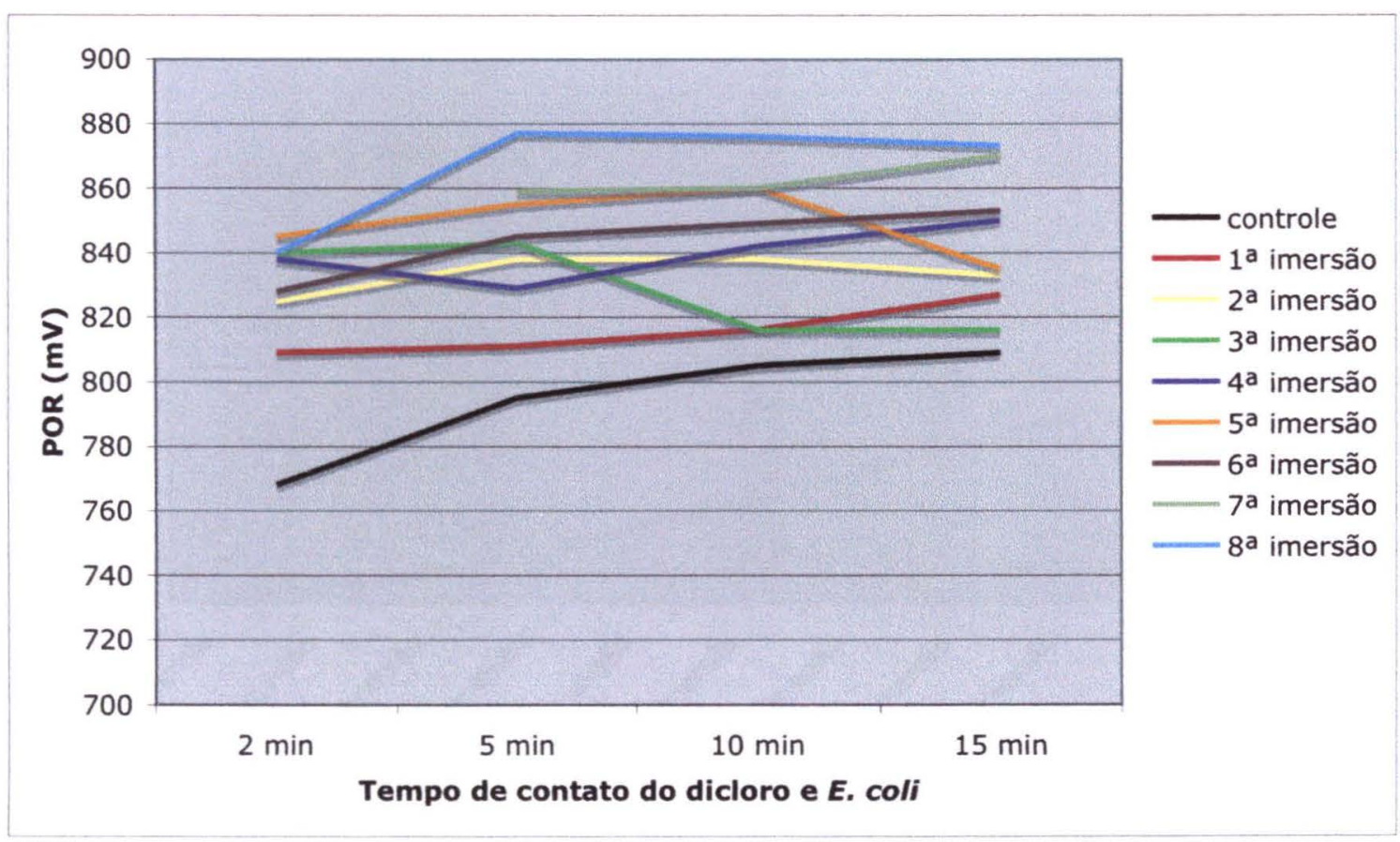

Figura 8 - Comportamento da água sem imersão (controle) e mais oito imersões sucessivas contendo matéria orgânica proveniente dos cortes de alface americana* segundo o potencial de óxido-redução (POR) em milivolts $(\mathrm{mV})$, ao longo de 15 minutos de contato do inóculo de $E$. coli com uma solução "envelhecida"** de dicloro-S-triazinatriona sódica diidratada $\left(\mathrm{NaCl}_{2} \mathrm{C}_{3} \mathrm{~N}_{3} \mathrm{O}_{3}\right.$, Sumaveg®, $\left.200 \mathrm{mg} / \mathrm{L}\right)$, ensaio 4 .

* Matéria orgânica proveniente dos cortes de alface americana nas proporções de $1 \mathrm{~g}: 20$ $\mathrm{mL}$ ( $1^{\mathrm{a}}$ imersão), $2 \mathrm{~g}: 20 \mathrm{~mL}$ ( $2^{\mathrm{a}}$ imersão), $3 \mathrm{~g}: 20 \mathrm{~mL}$ ( $3^{\mathrm{a}}$ imersão), $4 \mathrm{~g}: 20 \mathrm{~mL}\left(4^{\mathrm{a}}\right.$ imersão), $5 \mathrm{~g}: 20 \mathrm{~mL}$ ( $5^{\mathrm{a}}$ imersão), $6 \mathrm{~g}: 20 \mathrm{~mL}$ ( $6^{\mathrm{a}}$ imersão), $7 \mathrm{~g}: 20 \mathrm{~mL}$ ( $7^{\mathrm{a}}$ imersão) e $8 \mathrm{~g}$ : $20 \mathrm{~mL}$ ( $8^{\mathrm{a}}$ imersão).

** Solução preparada antes do uso: $30 \min 1^{\mathrm{a}}$ imersão, $60 \mathrm{~min} 2^{\mathrm{a}}$ imersão, $90 \operatorname{min~} 3^{\mathrm{a}}$ imersão, $120 \mathrm{~min} 4^{\mathrm{a}}$ imersão, $150 \mathrm{~min} 5^{\mathrm{a}}$ imersão, $180 \mathrm{~min} 6^{\mathrm{a}}$ imersão, $210 \mathrm{~min} 7^{\mathrm{a}}$ imersão, 240 min $8^{\mathrm{a}}$ imersão e solução recém-preparada para a água sem imersão (controle). 


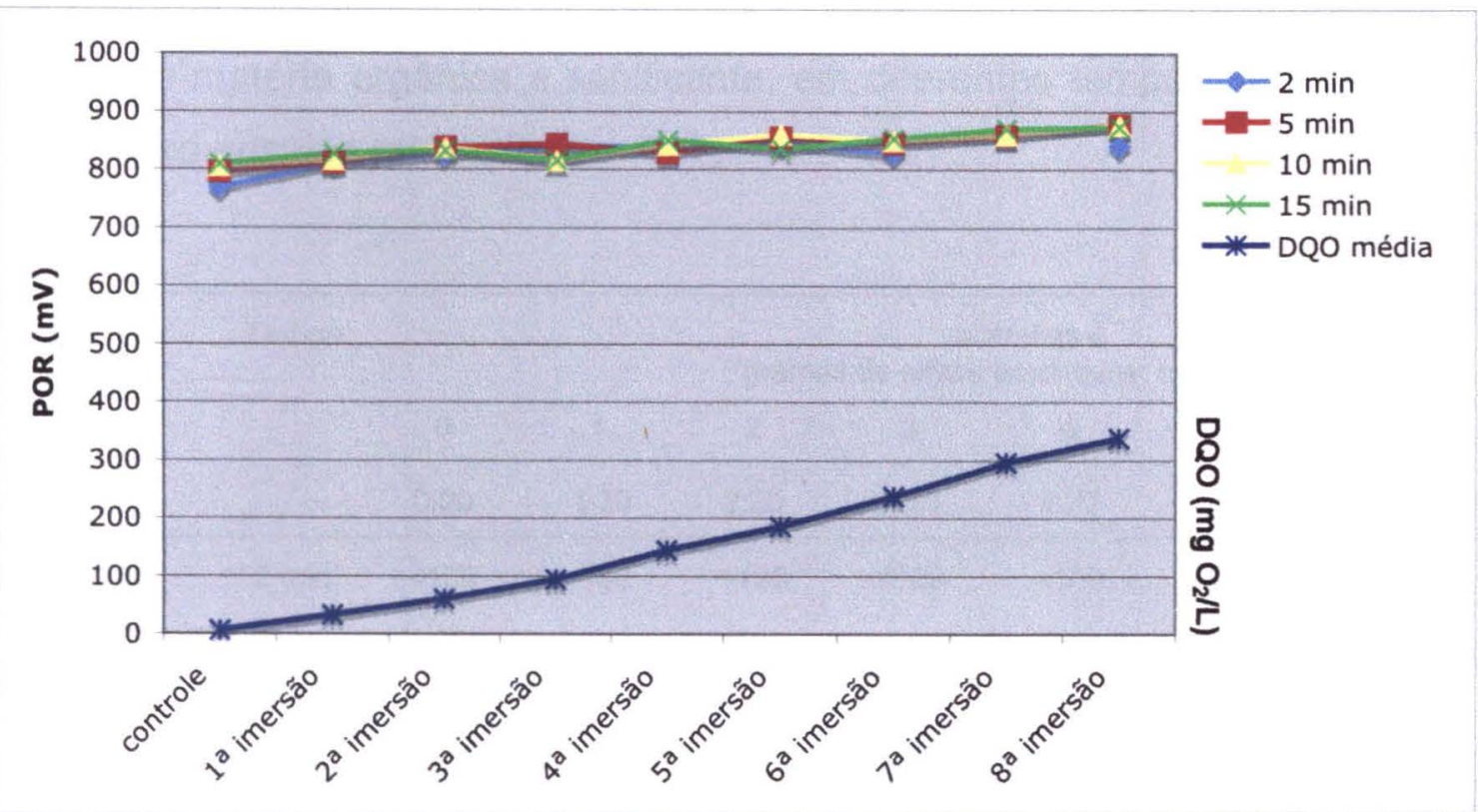

Figura 9 - Comparação da curva de demanda quimica de oxigênio (DQO)

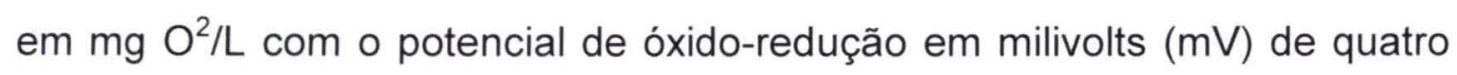
tempos de contato da solução "envelhecida"* de dicloro-S-triazinatriona sódica diidratada $\left(\mathrm{NaCl}_{2} \mathrm{C}_{3} \mathrm{~N}_{3} \mathrm{O}_{3}\right.$, Sumaveg $\left.{ }^{\circledR}, 200 \mathrm{mg} / \mathrm{L}\right)$ com o inóculo de $E$. coli em água sem imersão (controle) e mais oito imersões sucessivas contendo matéria orgânica proveniente dos cortes de alface americana* ${ }^{* *}$, ensaio 4.

* Solução preparada antes do uso: $30 \min 1^{a}$ imersão, $60 \operatorname{min~} 2^{a}$ imersão, $90 \min 3^{a}$ imersão, $120 \min 4^{\mathrm{a}}$ imersão, $150 \min 5^{\mathrm{a}}$ imersão, $180 \mathrm{~min} 6^{\mathrm{a}}$ imersão, $210 \mathrm{~min} 7^{\mathrm{a}}$ imersão, 240 min $8^{\mathrm{a}}$ imersão e solução recém-preparada para a água sem imersão (controle).

** Matéria orgânica proveniente dos cortes de alface americana nas proporções de $1 \mathrm{~g}: 20$ $\mathrm{mL}\left(1^{\mathrm{a}}\right.$ imersão), $2 \mathrm{~g}: 20 \mathrm{~mL}\left(2^{\mathrm{a}}\right.$ imersão), $3 \mathrm{~g}: 20 \mathrm{~mL}$ ( $3^{\mathrm{a}}$ imersão), $4 \mathrm{~g}: 20 \mathrm{~mL}\left(4^{\mathrm{a}}\right.$ imersão), $5 \mathrm{~g}: 20 \mathrm{~mL}$ ( $5^{\mathrm{a}}$ imersão), $6 \mathrm{~g} \mathrm{:} 20 \mathrm{~mL}$ (6 $6^{\mathrm{a}}$ imersão), $7 \mathrm{~g}: 20 \mathrm{~mL}$ ( $7^{\mathrm{a}}$ imersão) e $8 \mathrm{~g}$ : $20 \mathrm{~mL}$ ( $8^{\mathrm{a}}$ imersão). 
Tabela 7 - Contagens de E. coli ATCC 11229 recuperadas em imersões contendo matéria orgânica e sanificante, em diferentes tempos de contato, nos quatro ensaios realizados.

\begin{tabular}{|c|c|c|c|c|c|c|c|c|c|c|}
\hline \multirow[t]{3}{*}{ Sanificante } & \multirow[t]{3}{*}{ Tempo } & \multicolumn{9}{|c|}{$\begin{array}{l}\text { Imersões e } \\
\text { gramas de alface americana: } \mathrm{mL} \text { de água }\end{array}$} \\
\hline & & 0 & 1 & 2 & 3 & 4 & 5 & 6 & 7 & 8 \\
\hline & & $0: 20$ & $1: 20$ & $2: 20$ & $3: 20$ & $4: 20$ & $5: 20$ & $6: 20$ & $7: 20$ & $8: 20$ \\
\hline \multirow{3}{*}{$\begin{array}{l}\text { Dióxido de } \\
\text { cloro } \\
\text { ENSAIO } 1\end{array}$} & $2 \min$ & $<100$ & $<100$ & $<100$ & $<100$ & $<100$ & - & - & - & - \\
\hline & $5 \mathrm{~min}$ & $<100$ & $<100$ & $<100$ & $<100$ & $<100$ & - & - & - & - \\
\hline & $10 \mathrm{~min}$ & $<100$ & $<100$ & $<100$ & $<100$ & $<100$ & - & - & - & - \\
\hline \multirow{2}{*}{$\begin{array}{l}\text { Hipoclorito de } \\
\text { sódio }\end{array}$} & $2 \min$ & $1,7 \times 10^{7}$ & $1,8 \times 10^{6}$ & $<100$ & $<100$ & $<100$ & $<100$ & $<100$ & $<100$ & $<100$ \\
\hline & $5 \mathrm{~min}$ & $<100$ & $<100$ & $<100$ & $<100$ & $<100$ & $<100$ & $<100$ & $<100$ & $<100$ \\
\hline \multirow[t]{2}{*}{ ENSAIO 2} & $10 \mathrm{~min}$ & $<100$ & $<100$ & $3,9 \times 10^{3}$ & $<100$ & $<100$ & $<100$ & $<100$ & $<100$ & $<100$ \\
\hline & $15 \mathrm{~min}$ & $<100$ & $<100$ & $<100$ & $8,3 \times 10^{5}$ & $<100$ & $3 \times 10^{5}$ & $<100$ & $<100$ & $<100$ \\
\hline Hipoclorito de & $2 \min$ & $10^{4}$ & $<100$ & $<100$ & $<100$ & $<100$ & $<100$ & $<100$ & $7,5 \times 10^{4}$ & $2,2 \times 1 C$ \\
\hline $\begin{array}{l}\text { sódio } \\
\text { (solução }\end{array}$ & $5 \min$ & $<100$ & $<100$ & $<100$ & $<100$ & $<100$ & $<100$ & $<100$ & $<100$ & $5,8 \times 1 C$ \\
\hline "envelhecida") & $10 \mathrm{~min}$ & $<100$ & $6,5 \times 10^{7}$ & $<100$ & $<100$ & $8,2 \times 10^{4}$ & $<100$ & $<100$ & $<100$ & $1,4 \times 1 C$ \\
\hline ENSAIO 3 & $15 \mathrm{~min}$ & $<100$ & $<100$ & $<100$ & $<100$ & $<100$ & $<100$ & $<100$ & $<100$ & $4 \times 10^{2}$ \\
\hline Dicloro & $2 \min$ & $<100$ & $<100$ & $<100$ & $<100$ & $<100$ & $<100$ & $<100$ & $<100$ & $<100$ \\
\hline STSD* & $5 \mathrm{~min}$ & $<100$ & $<100$ & $<100$ & $<100$ & $<100$ & $<100$ & $<100$ & $<100$ & $<100$ \\
\hline $\begin{array}{l}\text { (solução } \\
\text { "envelhecida") }\end{array}$ & $10 \mathrm{~min}$ & $<100$ & $<100$ & $<100$ & $<100$ & $<100$ & $<100$ & $<100$ & $<100$ & $<100$ \\
\hline ENSAIO 4 & $15 \mathrm{~min}$ & $<100$ & $<100$ & $<100$ & $<100$ & $<100$ & $<100$ & $<100$ & $<100$ & $<100$ \\
\hline
\end{tabular}

* Dicloro-S-triazinatriona sódica diidratada. 
Tabela 8 - Número em escala logarítmica de unidades formadoras de colônias de E. coli ATCC 11229 reduzidas em imersões contendo matéria orgânica e sanificante, nos ensaios com hipoclorito de sódio (ensaios 2 e 3).

Sobrevivência

Log do número de UFC de $E$. coli reduzidas por $\mathrm{mL}$ de E. coli

Hipoclorito de sódio

ENSAIO 2

$\begin{array}{lcc}\text { controle } & \text { sem redução* } & 7,1 \\ 1^{\mathrm{a}} \text { imersão } & 0,7 & 3,3 \\ 2^{\mathrm{a}} \text { imersão } & 3,3 & 11,1 \\ 3^{\mathrm{a}} \text { imersão } & 1,0 & 11,1 \\ 4^{\mathrm{a}} \text { imersão } & 6,9 & 6,2 \\ 5^{\mathrm{a}} \text { imersão } & 1,5 & 11,1 \\ 6^{\mathrm{a}} \text { imersão } & 6,9 & 11,1 \\ 7^{\mathrm{a}} \text { imersão } & 6,9 & 6,3 \\ 8^{\mathrm{a}} \text { imersão } & 6,9 & 8,5^{\text {** }}\end{array}$

Hipoclorito de sódio (solução "envelhecida") ENSAIO 3

* Cotagem superior ao inóculo - água sem imersão (controle), 2 min de contato $\left(1,7 \times 10^{7}\right.$ $\mathrm{UFC} / \mathrm{mL}$ )

** Contagem em todos tempos de contato da $8^{a}$ imersão variando a redução de 5,8 a $8,5 \log$ de UFC/mL 


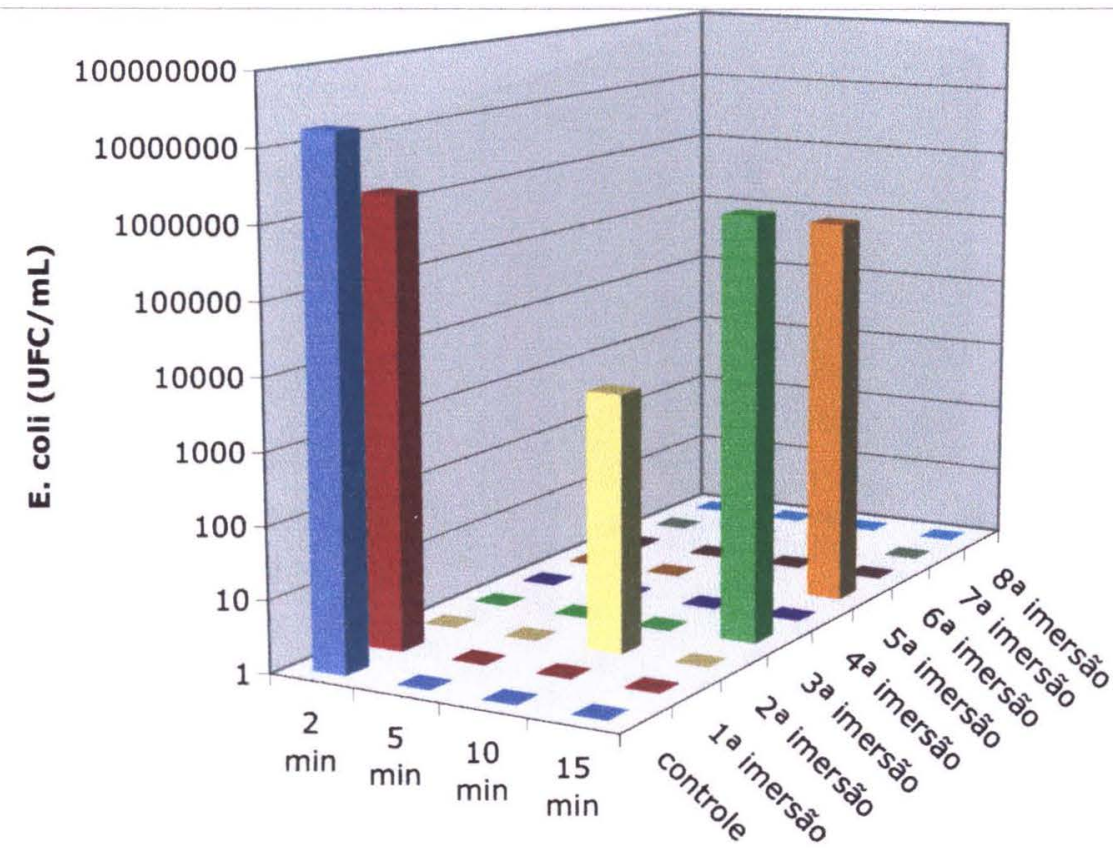

Figura 10 - Contagem de E. coli nas imersões utilizando solução de hipoclorito de sódio, ensaio 2. 


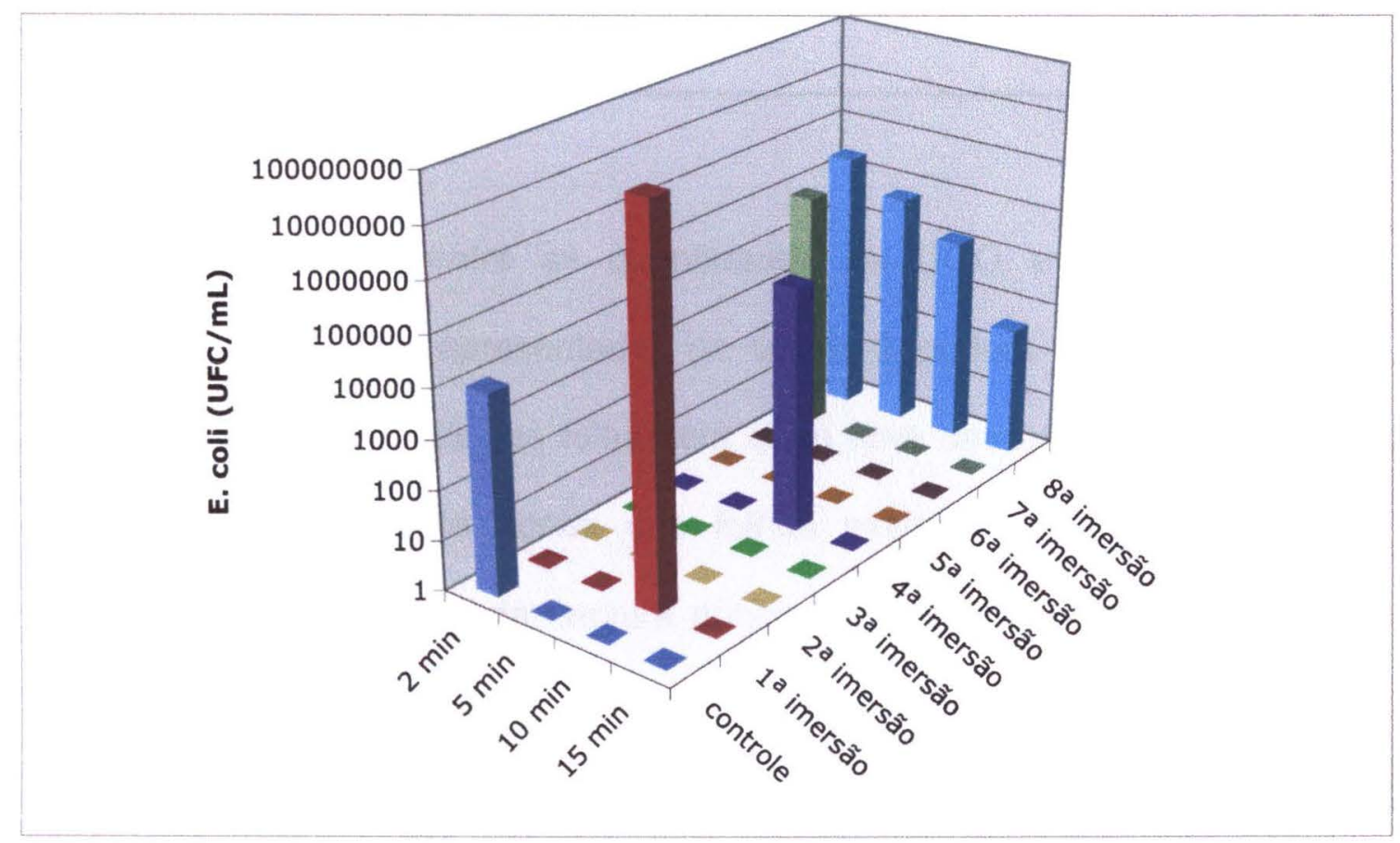

Figura 11 - Contagem de E. coli nas imersões utilizando solução "envelhecida" de hipoclorito de sódio, ensaio 3. 
As diferenças entre as quantidades de DQO em $\mathrm{mg} \mathrm{O}^{2} / \mathrm{L}$ nas repetições dos testes apresentados na tabela 2 podem ser atribuídas às variações de maturidade das folhas em cada uma das amostras, maior ou menor concentração de cortes das folhas externas ou internas, maior proximidade ou distância da nervura principal das folhas, embora tenha-se objetivado constituir os lotes amostrais com pedaços de várias partes da folha de forma a torná-lo mais representativo. Outra justificativa para a variedade encontrada é com relação ao método de análise da $D Q O$, pois segundo PERALTA-ZAMORA et al. (2005) a reprodutibilidade é baixa e pode haver desvios de até $30 \%$.

Por outro lado, os mesmos autores consideram a demanda química de oxigênio (DQO) uma prova comumente utilizada para avaliar o potencial poluente em uma amostra, pois indica grande parte da matéria orgânica presente na solução. Além disso, trata-se de um parâmetro consolidado e que faz parte das legislações ambientais do mundo todo e portanto é utilizado na rotina de muitos laboratórios (PERALTA-ZAMORA et al. 2005).

Os testes de eficácia de sanificantes contra microrganismos patogênicos humanos em produtos hortifrutícolas são realizados expondo o microrganismo à ação do desinfetante para estabelecer sua capacidade de destruição. Em muitos casos o microrganismo utilizado foi isolado no homem a partir de doenças implicadas com o consumo de hortifrutícolas. Em muitos outros trabalhos os microrganismos são inoculados nos produtos 
hortifrutícolas para depois expô-los ao sanificante que irá ser testado. Todos estes estudos envolvem muitas dificuldades metodológicas (BEUCHAT et al. 2001).

No presente estudo foi utilizada uma metodologia similar ao método de suspensão (TOMASINO 2005), porém foi introduzida a variável matéria orgânica proveniente do corte padronizado da alface americana.

O comportamento da reação química de contato do sanificante com a água, a matéria orgânica e o inóculo foram medidos por meio da modificação do potencial elétrico na solução.

No primeiro ensaio, utilizando dióxido de cloro da marca comercial Tecsaclor®, verificou-se que durante os 10 minutos de contato do sanificante diluído nas imersões de alface com o inóculo de E. coli, a medição do POR manteve-se aumentando ao longo do tempo de contato, como pode ser observado na figura 3 . A medição do potencial elétrico da reação com dióxido de cloro registrou valores sempre acima de $417 \mathrm{mV}$ (2 minutos de contato na água sem imersão, usada como controle) e inferiores a $549 \mathrm{mV}$ registrado a 10 minutos da reação na terceira imersão (tabela 3), bem abaixo dos $700 \mathrm{mV}$ preconizados comercialmente (SUSLOW 2004, SAPERS 2001). Por outro lado, DU et al. (2002) observaram que o dióxido de cloro com geração de gás in situ foi efetivo na descontaminação de Listeria monocytogenes de maçãs inteiras, principalmente na superfície da polpa. Com $8 \mathrm{mg} / \mathrm{L}$ de dióxido de cloro por 30 minutos foi possível eliminar até 5 logs, mesmo das cavidades da maçã. 
A superposição gráfica da curva média de DQO com o potencial elétrico, medidos em todas as imersões e tempos de contato do dióxido de cloro, não apresentou modificações que sugiram a interferência do aumento da matéria orgânica na reação (figura 3). Porém, nesse ensaio foram utilizados apenas quatro imersões contendo matéria orgânica, sendo que a concentração média máxima de $\mathrm{DQO}$ foi de $143,8 \mathrm{mg} \mathrm{O} \mathrm{O}^{2} / \mathrm{L}$ na quarta imersão (tabela 2).

A efetividade a baixas concentrações e a menor reatividade com compostos orgânicos da solução pode explicar a eficácia observada nos testes realizados com matéria orgânica de quatro imersões do ensaio 1.

O segundo e terceiro ensaios foram realizados utilizando hipoclorito de sódio da marca comercial Virex Plus FLV 2\%®. O preparo da solução sanificante com água das imersões de alface americana do terceiro ensaio foi realizado em tempos diferentes, anteriores à colocação do inóculo para propositalmente causar o "envelhecimento" da solução. Os tempos de preparo foram 30 min para a primeira imersão e mais 30 minutos para cada imersão, de maneira que a solução da oitava imersão, no momento da mistura do inóculo, já encontrava-se preparada há 240 minutos. Este mesmo procedimento foi utilizado no ensaio 4 , em que foi testada a solução de dicloro-S-triazinatriona (tabela 6).

Como é possível verificar na comparação das figuras 5 e 6 relativas aos ensaios com hipoclorito de sódio, nas sétimas e oitavas imersões as medições do POR encontravam-se entre 300 e $400 \mathrm{mV}$, indicando muito pouca reatividade do processo oxidativo. O mesmo não ocorreu com a 
solução "envelhecida" de dicloro-S-triazinatriona, embora também fosse preparada antes do uso (figura 9). Estes resultados sugerem que a diminuição da reatividade do hipoclorito de sódio tenha se dado pelo excesso de matéria orgânica, mas as contagens microbianas discutidas posteriormente também indicam que o "envelhecimento" da solução de hipoclorito pode ter contribuído para a menor eficácia.

BEUCHAT e RYU (1997) relataram que aplicando 2000 mg/L de cloro em cubos de melão, a redução do inóculo de cinco sorotipos de Samonella foi de apenas 1 log. A mesma concentração de cloro usada em sementes de alfafa conseguiu eliminar a mistura de salmonelas a um nível não-detectável. Os autores justificam que a diferença de comportamento do sanificante se dá pela diferença de matéria proveniente dos cubos de melão.

PIROVANI et al. (2004), estudando a redução da concentração de cloro durante o processo de desinfecção de alface para o desenvolvimento de um modelo matemático, encontraram que a eliminação dos microrganismos é maior quando aumenta a concentração de cloro e quando diminui a proporção de quilogramas de alface por litros de água. No estudo também foram utilizados cortes padronizados de alface para simular a matéria orgânica presente na solução sanificante. O teor de matéria orgânica não foi mensurado e as proporções de quilogramas de alface para litros de água eram de 1:20, 1:35 e 1:50. Comparando-se as proporções com o presente estudo verifica-se que PIROVANI et al. (2004) trabalharam possivelmente com menores teores de matéria orgânica, sendo sua mais crítica situação (1:20) correspondente à primeira imersão da seqüência de 
oito, ainda que a alface fosse mais picada $(0,5 \mathrm{~cm}$ por $2-3 \mathrm{~cm}$ contra $5 \mathrm{~cm}$ por $5 \mathrm{~cm}$ no atual estudo). A alta diluição do modelo utilizado pelos autores pode explicar a observação de que a depleção do cloro livre foi similar em todas as proporções alface/água em $\mathrm{pH}$ estabilizado em 7. Resultado semelhante havia sido encontrado em trabalho anterior usando espinafre, mas com poucos cortes (PIROVANI et al. 2001).

Quanto ao dicloro-S-triazinatriona, os testes do ensaio 4 sugerem que no nível de matéria orgânica alcançada de até $337 \mathrm{mg} \mathrm{O} / \mathrm{L}$, e na condição de "envelhecimento" por 240 minutos, a reatividade da solução não se alterou, permanecendo sempre acima de $768 \mathrm{mV}$ (figura 9). Embora em níveis mais elevados de POR do que o dióxido de cloro, o comportamento frente à matéria orgânica foi semelhante (figura 3).

As oito imersões com matéria orgânica, a água sem imersão (controle) e os quatro tempos de contato do inóculo de E. coli ATCC 11229 com as quatro soluções sanificantes foram analisados para verificar 0 número de bactérias eliminadas. Os resultados das contagens foram descritos na tabela 7.

A bactéria utilizada no inóculo ( $E$. coli ATCC 11229) é tradicionalmente empregada em ensaios de eficácia de desinfetantes e recomendada pela AOAC (TOMASINO 2005). SILVA et al. (2003) realizaram testes comparativos com E. coli ATCC 11229 e E. coli O157:H7 e verificaram - comportamento semelhante no teste de suspensão com produtos comerciais a base de hipoclorito de sódio, dicloro isocianurato de sódio e cloreto de benzalcônio, todos a 100 e $200 \mathrm{mg} / \mathrm{L}$. Os autores sugerem que $\circ$ 
uso da E. coli ATCC 11229 é um modelo adequado para a prevenção da $E$. coli O157:H7.

No presente estudo, os ensaios com dióxido de cloro e com dicloro-Striazinatriona não apresentaram contagens de microrganismos, mas nos ensaios com hipoclorito de sódio foram verificadas contagens em todas as imersões, exceto na sexta imersão. Na oitava imersão do ensaio 3 - com hipoclorito - foram verificadas contagens em todos os tempos de contato (tabela 7). Estes resultados coincidem com as observações das medições do POR, pois nos sanificantes dióxido de cloro e dicloro-S-triazinatriona não foram verificadas modificações elétricas importantes ao longo dos tempos de contato e do aumento da matéria orgânica.

Comparando-se a porcentagem de eliminação de $E$. coli entre os dois ensaios em que foi utilizado o hipoclorito de sódio como sanificante, pode-se supor que a solução "envelhecida" foi menos eficaz que a solução preparada imediatamente antes do uso (figuras 10 e 11).

Em uma situação ideal, a solução de sanificante é preparada no momento do uso, mas de fato, com os sucessivos reaproveitamentos, as soluções podem permanecer prontas por longo tempo, além de receberem mais matéria orgânica em cada uso. Segundo as medições de POR do presente estudo, para o uso de hipoclorito de sódio, a sexta e sétima imersões foram criticas, pois foram registradas leituras sempre abaixo de $400 \mathrm{mV}$.

Com relação aos pontos em que foi verificada sobrevivência de bactérias, observou-se que o POR variou entre 316 e $509 \mathrm{mV}$. Valores 
dessa ordem só foram verificados nos ensaios com hipoclorito de sódio e em parte do ensaio com dióxido de cloro, embora para este último sanificante não tenham sido encontradas contagens de $E$. coli.

O tempo de contato de 2 minutos não se apresentou seguro para o hipoclorito de sódio, mesmo sem matéria orgânica (tabela 7). PIROVANI et al. (2004), nas condições do teste, não encontraram diferença na redução de microrganismos pelo aumento do tempo de contato (2, 5 e 8 minutos).

No presente estudo, em que a matéria orgânica foi utilizada como um interferente da reação do sanificante com a $E$. coli padrão, foram verificadas de zero (sem redução) a 8,5 reduções logarítmicas do microrganismo. Sendo que em seis pontos de análise dos ensaios com hipoclorito de sódio $200 \mathrm{mg} / \mathrm{L}$, as reduções logarítmicas foram inferiores a 5.

Comparando-se as reduções com os resultados de SILVA et al. (2003), que verificaram que pelo método de suspensão da AOAC a eficácia do sanificante hipoclorito de sódio 100 e $200 \mathrm{mg} / \mathrm{L}$ provocou mais de 5 reduções decimais, tanto para a cepa padrão E. coli ATCC 11229 como para a bactéria patogênica $E$. coli $\mathrm{O} 157: \mathrm{H} 7$, é possivel supor que fora das condições ideais propostas pelos testes de eficácia possa haver sobrevivência desses microrganismos.

Segundo BEUCHAT et al. (2001), a interpretação de resultados de estudos de eficácia de desinfetantes com tecidos vegetais lesados precisa levar em consideração que essas estruturas vegetais podem liberar compostos e fitoalexinas que também agem contra os microrganismos que possam estar sendo testados no experimento. Nesse caso, o sanificante 
poderia falsamente apresentar-se como mais eficaz. Por outro lado, os tecidos vegetais podem fornecer "abrigo" aos microrganismos e impedir seu contato com o sanificante. Esse pode ser o mecanismo que dificultou a redução dos microrganismos casualmente em diferentes imersões e tempos de contato, como pode ser verificado nos ensaios com hipoclorito de sódio.

Dentre os objetivos do presente estudo foi proposta a avaliação do uso de medidor de POR portátil, como mais um instrumento de campo que pudesse ser utilizado pela vigilância sanitária em visitas técnicas, e como instrumento de controle para os locais em que os alimentos de origem vegetal passam por alguma fase de desinfecção química em solução de sanificante. Devido ao grande número de sanificantes presentes no mercado, o órgão regulatório necessitaria de muitos "kits" de verificação para as diferentes substâncias. Além do que, os "kits" normalmente informam a concentração total do sanificante e não sua capacidade de reação.

Os resultados sugerem que o medidor de POR Tracer Pocketester 1742 foi capaz de registrar modificações na reatividade das soluções para três tipos diferentes de sanificantes oxidantes. Por outro lado, verificou-se a limitação do equipamento em retornar rapidamente das faixas de POR mais elevadas para valores mais baixos. Essa limitação ficou evidente nos ensaios 1 e 4 em que a cada início do tempo de contato das imersões consecutivas, o POR era mais alto que o inicial anterior (figuras 2 e 8).

Uma possível explicação para esta "memória" é que a diferença extrema de força iônica, em soluções com fortes oxidantes, dificulte a repolarização do sensor de platina. 
Ainda que o modelo testado apresente limitações, sua utilidade pode ser grande se o intervalo de tempo entre leituras for maior. A limpeza do eletrodo é um fator importante para o funcionamento adequado do equipamento, assim como a calibração e repouso em pH 4 por 10 minutos, ainda que o manual do equipamento declare que a calibração é automática (LAMOTTE 2005).

A fragilidade do sensor também é um limitante para seu uso no campo. Durante o período de testes foi necessário utilizar três eletrodos (cerca de 18 meses), embora todos os cuidados de manuseio fossem tomados de acordo com as orientações do manual. A assistência técnica foi dificultada pela falta de prática dos vendedores-técnicos com o uso do equipamento. Foi necessária uma intervenção via assistência técnica do fabricante LaMotte, dos Estados Unidos, para a elucidação dos problemas de funcionamento do equipamento.

O uso de um equipamento mais robusto, com maior capacidade de ajuste a diferentes faixas de força iônica, pode resultar em medições mais precisas e rápidas.

Mesmo não sendo totalmente conclusivos, os resultados indicam a viabilidade do emprego da medição do potencial de óxido-redução para o controle durante o uso de soluções sanificantes na desinfecção de produtos hortifrutícolas. 
1. Por meio da demanda química de oxigênio (DQO) foi possível quantificar a matéria orgânica de cortes padronizados de alface americana.

2. Dentre os sanificantes testados com matéria orgânica padronizada, foram consideradas eficazes a solução de dióxido de cloro marca comercial Tecsaclor® e de dicloro-S-triazinatriona sódica diidratada marca comercial Sumaveg ${ }^{\circledR}$ preparadas conforme a recomendação dos fabricantes.

3. O uso de medidor de POR mostrou-se promissor, mas o modelo portátil testado apresentou problemas de falta de robustez para o manuseio e dificuldade na assistência técnica. 
A determinação do POR para microrganismos de interesse em saúde pública pode auxiliar na produção de alimentos seguros ao consumidor, necessitando mais estudos para sua aplicação.

A possibilidade de correções "em tempo real" fornecidas pelo POR e baseadas em limites críticos adequa-se bem às exigências dos planos de Análise de Perigos e Pontos Críticos de Controle.

Considerando que as técnicas empregadas no processamento mínimo de hortifrutícolas não eliminam completamente contaminantes perigosos à saúde, se faz necessário um grande esforço para a melhoria da qualidade e segurança das matérias-primas no campo. A intensificação de ações educativas e fiscalizatórias neste segmento da cadeia produtiva deve ser considerada como uma alternativa para a produção de alimentos mais seguros para os consumidores.

Ainda que a qualidade dos produtos minimamente processados seja fortemente ligada com a qualidade da matéria-prima, estudos com sanificantes que levem em consideração a realidade do uso são necessários e podem contribuir para a melhoria dos processos. 


\section{Bibliografia}

Adams MR, HARTLEY AD, COX LJ. Factors affecting the efficacy of wahing procedures used in the production of prepared salads. Food Microbiol 1989; 6: 69-77.

Banco Mundial - Unidade de Gerenciamento do Brasil. Enfrentando o desafio das doenças não transmissiveis no Brasil [relatório on line]. Brasilia (DF); 2005. (Banco Mundial, Relatório n³2576-BR). Disponível em: <URL: http://www.cev.org.br/biblioteca/RelatorioBancoMundialBR.pdf> [2007 mai 18].

Bari ML, Inatsu Y, Kawasaki S, Nazuka E, Isshiki K. Calcinated calcium killing of Escherichia coli O157:H7, Salmonella, and Listeria monocytogenes on the surface of tomatoes. J Food Prot 2002; 65: 1706-1711.

Beuchat LR, Ryu JH. Produce handling and processing practices. Emerg Infec Diseases 1997; 3: 459-465.

Beuchat LR Standartization of a method to determine the efficacy of sanitizers in inactivating human pathogenic microorganisms on raw fruits and vegetables. J Food Prot 2001; 64:1079-1084. 
Beuchat LR Ecological factors influencing survival and growth of human pathogens on raw fruits and vegetables. Microbes Inf 2002; 4: 413-423.

Bonnas DS, Silva CC, Silva SA, Ferreira IM. Qualidade higiênico-sanitária de vegetais minimamente processados, comercializados no município de Uberlândia, MG. Hig Aliment 2005; 19(133): 100-103.

Brackett RE, Splittstoesser DF. Fruits and vegetables. In: Downes FP, ITO K, editores. Compendium of methods for the microbiological examination of foods. $4^{a}$ ed. Washington: APHA; 2001. p. 515-520.

Breene WM Healthfulness and nutritional quality of fresh versus processed fruits and vegetables: a review. Foodserv Research Inter 1994; 8:1-45.

Bruno LM, Queiroz AAM, Andrade APC, Vasconcelos NMV, Borges MF. Avaliação microbiológica de hortaliças e frutas minimamente processadas comercializadas em Fortaleza (CE). B Ceppa 2005; 23(jan/jun): 75-84.

Buck JW, Walcott RR, Beuchat LR. Recent trends in microbiological safety of fruits and vegetables. APSnet [online] 2003; (jan-feb). [1 tela] Disponível em: <URL: http: //www.apsnet.org/online/feature/safety/> [2005 jan 27] 
Caldwell KN, Anderson GL, Williams PL, Beuchat LR. Attraction of a freeliving nematode, Caenorhabditis elegans, to foodborne pathogenic bacteria and its potencial as a vector of Salmonella Poona for preharvest contamination of cantaloupe. J Food Protec 2003; 66:1964-1971.

California Department of Health Services-Food and Drug Branch, Food and Drug Administration-San Francisco District. Investigation of an Escherichia coli 0157:H7 outbreak associated with Dole pre-packageed spinach. Final March 21 2007. [relatório on line] California; 2007a. Disponível em: <URL: http://www.dhs.ca.gov/ps/fdb/HTML/Food/EnvInvRpt.htm> [2007 mai 15]

California Department of Health Services-Food and Drug Branch, Food and Drug Administration-San Francisco District. Addendum report to "Investigation of an Escherichia coli O157:H7 outbreak associated with Dole Pre-Packageed spinach. Final March 21 2007". [relatório on line] California; 2007b. Disponível em: <URL: http://www.dhs.ca.gov/ps/fdb/HTML/Food/EnvInvRpt.htm> [2007 mai 15]

Chitarra MIF. Processamento minimo de frutos e hortaliças. Viçosa: Centro de produções técnicas, 1998.

Curtis M, Franceschi O, Castro N. Listeria monocytogenes en vegetales minimamente procesados. Arch Latinoam Nutr 2002; 52: 1 - 10. 
Damasceno KSFSC, Stamford TLM, Alves MA. Vegetais minimamente processados: uma revisão. Hig Aliment 2001; 15(85): 20-25.

Daniel LA. Processos de desinfecção e desinfetantes alternativos na produção de água potável. $1^{\text {a }}$ ed. São Carlos: RiMa Arte e Textos; 2001.

Delaquis P, Stewart S, Cazaux S, Toivonen P. Survival and growth of Listeria monocytogenes and Escherichia coli 0157:H7 in ready-to-eat iceberg letuce washed in warm chlorinated water. J Food Prot 2002; 65: 459 - 464.

DeWaal CS, Johnson K, Bhuiya F. Outbreak alert - Closing the gaps in our federal food-safety net. [Relatório online] Washington (DC); 2006. (Center for Science in the Public Interest - CSPI). Disponível em: <URL: http://cspinet.org/foodsafety/outbreak_report.html> [2007 mai 15]

DiezGarcia RW. Reflexos da globalização na cultura alimentar: considerações sobre as mudanças na alimentação urbana. Rev Nutr 2003; 16: $483-492$.

$\mathrm{Du} \mathrm{J}$, Han $\mathrm{Y}$, Linton $\mathrm{RH}$. Inactivation by chlorine dioxide gas $\left(\mathrm{ClO}^{2}\right)$ of Listeria monocytogenes spotted onto different apple surfaces. Food Microbiol 2002; 19: $481-490$. 
Escudero ME, Velázquez L, DI Genaro MS, Guzmán AM. Effectiveness of various disinfectants in the elimination of Yersinia enterocolitica on fresh lettuce. J Food Prot 1999; 62: 665-669.

Francis G, Thomas C, O'Beirrne D. The microbiological safety of minimally processed vegetables. Int J Food Sci Technol 1999; 34: 1-22.

Fröder H. Emprego de um método molecular para avaliar a presença de Listeria monocytogenes em saladas de hortaliças folhosas minimamente processadas. São Paulo; 2005. [Dissertação de mestrado - Faculdade de Ciências Farmacêuticas da USP].

Furlaneto L, Santini MS, Velasco FAS. Análise microbiológica de vegetais e hortaliças minimamente processadas. Hig Aliment 2005; 19(131): 68-71.

Greenberg AE, Clesceri LS, Eaton AD. Standard methods for the examination of water and wastewater. $18^{\mathrm{a}}$ ed. Washington: American Public Health Association; 1992. Part 5000 - Aggregate organic constituents; p. 5-6 a 5-8.

Gunes G, Splittstesser DF, Lee CY. Microbial Quality of fresh potatoes: effect of minimal processing. J Food Protec 1997; 60:863-866. 
IBGE - Instituto Brasileiro de Geografia e Estatística. Pesquisa de orçamentos familiares 2002-2003 Primeiros resultados - Brasil e Grandes regiões. Rio de Janeiro, RJ; 2004.

IDEC. Teste do Idec constata: vegetais pré-higienizados oferecem riscos ao consumidor. [online]. 2004. Dispnivel em <URL: http://www.idec.org.br/emacao.asp?id=599> [2007 mai 20]

Kaneko K, Hayashidani H, Ohtomo Y, Kosuge J, Kato M, Takahashi K et al. Bacterial contamination of redy-to-eat foods and fresh products in retail shops and food factories. J Food Prot 2002; 62: 644-649.

Kim C, Hung, Brackett R, Lin C. Efficacy of electrolyzed oxidizing water in inactivating Salmonella on alfafa seeds and sprouts. J Food Prot 2003; 66: 208-214.

LaMotte. Tracer Pocketester ORP code 1742. Chestertown [Maryland, EUA]; 2005. [manual de uso do equipamento Tracer Pocketester 1742 online].

Disponivel em:

URL<http://www.lamotte.com/pages/common/instruct/index.html> [2005 nov 21] 
Landgraf M, Nunes TP. Microbiologia em frutas e hortaliças processadas. In: $4^{\circ}$ Encontro Nacional sobre Processamento Mínimo de Frutas e Hortaliças e $1^{\circ}$ Simpósio Ibero-americano de Vegetais Frescos Cortados; 2006 abr 4-7; São Pedro. Piracicaba: USP/ESALQ; 2006. p. 60-64.

Lucchesi G. Globalizacão e vigilância sanitária. Os rumos da vigilância sanitária no Brasil. Rio de Janeiro; 2001. [Tese de doutorado ENSP/FIOCRUZ].

Ministério da Integração Nacional. Secretaria de Infra-Estrutura Hídrica. A importância dos pré-processados. FrutiFatos - Informação para a fruticultura irrigada 1999; 1(1): 16-18.

Ministério da Integração Nacional. Secretaria de Infra-Estrutura Hídrica. Produtor, prepara-se: o consumidor quer mais. FrutiFatos - Informação para a fruticultura irrigada $2002 ; 2(2):$ 1-65.

Ministério da Integração Nacional. Secretaria de Infra-Estrutura Hídrica. Pesquisa em Minas e Rio revela o consumidor de hortifruti. FrutiFatos Informação para a fruticultura irrigada 2003; 4(out): 1-52.

Ministério da Saúde. Resolução RDC no 12, de 02 de janeiro de 2001. Aprova o Regulamento Técnico sobre padrões microbiológicos para alimentos. Diário Oficial da União; Poder Executivo. 10 jan 2001. 
Ministério da Saúde. Secretaria de Atenção à Saúde. Coordenação-Geral da Política de Alimentação e Nutrição. Guia alimentar para a população brasileira: Promovendo a alimentação saudável. Edição especial. Brasília (DF): Ministério da Saúde; 2005. (Série A. Normas e Manuais Técnicos).

Ministério do Desenvolvimento, Indústria e Comércio Exterior. Pro Teste avalia saladas prontas e encontra pulgões nas alfaces. [on line] 2004. Disponivel em: <URL:http://www.portaldoconsumidor.gov.br/noticia.asp?busca=sim\&id=238 1> [2007 mai 22].

Nascimento MS, Silva N, Catanozi MPLM. Avaliação microbiológica de frutas e hortaliças frescas, comercializadas no município de Campinas - SP. Hig Aliment 2003; 17(114/115): 73-76.

O'Connor-Shaw RE, Roberts R, Ford AL, Nottingham SM. Shelf life of minimally processed honeydew, kiwifruit, papaya, pineaplle and cantaloupe. J Food Sci 1996; 59:1202-1215.

OzFoodNet. Burden and causes of foodborne disease in Austrália: Annual reporto f the OzFoodNet network, 2005. Commun Dis Intell [periódico online] 2006; 30(3): 278-300. Disponível em: <URL: http://www.health.gov.au/internet/wcms/publishing.nsf/Content/2006+issues$1>$ [2007 mai 15]. 
Powell DA, Bobadilla-Ruiz M, Whitfield A, Griffiths MW, Luedtke A. Development, implementation, and analysis of an on-farm food safety program for the production of greenhouse vegetables. J Food Prot 2002; 65: 918-923.

Peralta-Zamora P, Cordeiro GA, Nagata N. Utilização de regressão multivariada para avaliação espectrofotométrica da demanda química de oxigênio em amostras de relevância ambiental. Quim Nova 2005; 28: 838841.

Pirovani M, Guemes DR, Piagentini AM. Predictive models for available chlorine depletion and total microbial count reduction during washing of fresh cut spinach. J Food Scie 2001; 66: 860-864.

Pirovani M, Piagentini A, Guemes D, Arkwright S. Reduction of chlorine concentration and microbial load during washing-disinfection of shredded lettuce. Int J Food Sci Technol 2004; 39: 341-347. 
Prado SPT, Bergamini AMM, Aquino AL, Capuano DM, Ribeiro EGA, Rocha GM. Avaliação microbiológica, parasitológica e da rotulagem de hortaliças minimamente processadas e higienizadas, comercializadas em Ribeirão Preto, SP. In: Anais do $3^{\circ}$ Simbravisa - Simpósio brasileiro de vigilância sanitária [CD ROM]; 2006 nov 26-29; Florianópolis (BR). São Paulo: Faculdade de Saúde Pública USP e Centro Colaborador em Vigilância Sanitária; 2006.

Prazak AM, Murano EA, Mercado I, Acuff G. Prevalence of Listeria monocytogenes during production and postharvest processing of cabbage. $\mathrm{J}$ Food Prot 2002; 65: 1728-1734.

Pulse Instruments. Wash water sanitation by ORP fruits and vegetables [online] Disponível em: <URL: http://www.orpmeter.com/orp_freshproduce.htm> [2005 jan 27]

Rojo JER. Aplicaciones de Alimentación Química: Mediciones y Procesos de Tratamiento Confiables. Água Latinoamérica. [online] 2002; 2 (4): [1 tela] Available from: <URL:

http://www.agualatinoamerica.com/NewsView.cfm?pkArticlelD=42> [2005 jan 27]

Rolle RS, Chism GW. Physiological consequences of minimally processed fruits and vegetables. J Food Quality 1987; 10: 157-177. 
Santaella SRR, Psillakis CN, Almeida CG, Okazaki MM, Cabral NT, Quarentei SS, Mesquita F, Santos TBA, Nitzsche T. Hortifrutícolas minimamente processadas: necessidade de legislação específica para atender às inovações tecnológicas e à inocuidade alimentar. In: Anais do $3^{\circ}$ Simbravisa - Simpósio brasileiro de vigilância sanitária [CD ROM]; 2006 nov 26-29; Florianópolis (BR). São Paulo: Faculdade de Saúde Pública USP e Centro Colaborador em Vigilância Sanitária; 2006.

Santos HS, Muratori MCS, Lopes JB. Condições higiênico-sanitárias de cenoura minimamente processada comercializada em supermercados de Teresina, PI. Hig Aliment 2005; 19(131): 86-90.

Santos TBA, Almeida CG, Pereira JL, Okazaki MM, Silva N, Junqueira VCA. Qualidade microbiológica de vegetais minimamente processados comercializados em Campinas - SP. In: Anais do $3^{\circ}$ Simbravisa - Simpósio brasileiro de vigilância sanitária [CD ROM]; 2006 nov 26-29; Florianópolis (BR). São Paulo: Faculdade de Saúde Pública USP e Centro Colaborador em Vigilância Sanitária; 2006.

Sanz S, Giménez M, Olarte C. Survival and growth of Listeria monocytogenes and enterohemorrhagic Escherichia coli $0157: \mathrm{H} 7$ in minimally processed artichokes. J Food Prot 2003; 66: 2203-2209. 
Sapers GM, Efficacy of washing and sanitizing methods for disinfection of fresh fruit and vegetable products. Food Technol Biotechnol 2001; 39:305311.

Schlindwein MM. Influência do custo de oportunidade do tempo da mulher sobre o padrão de consumo alimentar das famílias brasileiras. Piracicaba; 2006. [Tese de doutorado - Escola Superior de Agricultura Luiz de Queiroz USP].

Sharma RR, Demirci A, Beuchat LR, Fett WF. Inativation of Escherichia coli 0157:H7 on inoculated alfafa seeds with ozonated water and heat treatment. J Food Prot 2002; 65: 447-451.

Silva N, Silveira NFA, Yokoya F, Okazaki MM. Ocorrência de Escherichia coli 0157:H7 em vegetais e resistência aos agentes de desinfecção de verduras. Cienc Tecnol Aliment 2003, 23(2): 167-173.

Solomon E, Pang H-J, Matthews KR. Persistence of Escherichia coli O157:H7 on letuce plants following spray irrigation with contaminated water. J Food Prot 2003; 66: 2198-2202. 
Stan SD, Daeschel M. Reduction of Salmonella enterica on alfafa seeds with acidic electrolyzed oxidizing water and enhanced uptake of acidic electrolyzed oxidizing water into seeds by gas exchange. J Food Prot 2003; 66: 2017-2022.

Suslow T, Wu J, Fett W, Harris LJ. Detection and elimination of Salmonella Mbandaka from naturally contaminated alfafa seed by treatment with heat or calcium hypochlorite. J Food Prot 2002; 65: 452-458.

Suslow TV. Oxidation-redution potencial ORP for water disinfection monitoring, control, and documentation. Oakland; 2004 [online Publication 8149 - University of California DANR]. Disponível em: <URL: http://anrcatalog.ucdavis.edu/pdf/8149.pdf> [2006 jan 27]

Szabo EA, Simons L, Coventry MJ, Cole MB. Assessment of control measures to achieve a food safety objective of less than 100 CUF of Listeria monocytogenes per gram at the point of consumption for fresh precut iceberg lettuce. J Food Prot 2003; 66: 256-264.

Takayanagui OM, Febrônio LHP, Bergamini AM, Okino MHT, Castro e Silva AAMC, Santiago R. Fiscalização de hortas produtoras de verduras do município de Ribeirão Preto, SP. Rev Soc Bras Med Trop 2000; 33:169-174. 
Tomasino S. Disinfectants. In: Horwitz W Latimer Jr GW, editors. Official Methods of Analysis of AOAC Internacional. $18^{a}$ ed. (Gaithersburg): AOAC International; 2005. Chap. 6 p. 1-19.

Venkitanarayanan K, Lin C, Bailey H, Doyle M. Inactivation of Escherichia coli 0157:H7, Salmonella enteritidis and Listeria monocytogenes on apples, oranges, and tomatoes by lactic acid with hydrogen peroxide. J Food Prot 2002; 65: 100-105.

Wachtel MR, Whitehand LC, Mandrell RE. Prevalence of Escherichia coli associated with a cabbage crop inadvertently irrigated with partially treated sewage wastewater. J Food Prot 2002; 65: 471-475.

Yu K, Newman MC, Archbold DD, Hamilton-Kemp TR. Survival of Escherichia coli $\mathrm{O} 157: \mathrm{H} 7$ on strawberry fruit and reduction of the pathogen population by chemical agents. J Food Prot 2001; 64: 1334-1340. 